\title{
Odmowa uznania w Polsce rozwodu talaq na tle prawnoporównawczym
}

\begin{abstract}
The article deals with the recognition of talaq divorces (repudiation) in Poland and discusses reasons to oppose thereto. There are no doubts that repudiation of a wife, as known in Islamic legal systems, is contrary to fundamental principles of the Polish legal system. First, talaqs are discriminatory since they are available only for the men. The equality of spouses is thus violated. Second, the principle of the stability of marriage is infringed, given that repudiation does not often require to satisfy any conditions or requirements (other than repeating three times the word talaq). The author argues, however, that despite being in clear violation of the Polish public policy, talaq divorces should sometimes be recognized. In each and every case, the court must assess the individual circumstances of the case at hand. In particular, the recognition might be justified if the links of the case with the forum are weak. Likewise, if considerable time has passed since the divorce and the spouses to the repudiated marriage started new lives (especially entered new marriages), might the court refrain from enforcing Polish public policy. The court should also investigate the details of the talaq in question, because the laws and practice of the various Muslim countries differ considerably. Not all talaqs are of the same kind. It is relevant to what extent the given talaq was unilateral or whether the woman has somehow consented to divorce and the degree of financial protection offered to the repudiated spouse. The involvement of the public authority which ensures that due process is observed and women's rights are protected, might also justify recognition of the talaq divorce.
\end{abstract}

Keywords: talaq, divorce by repudiation, islamic legal systems, sharia law, recognition of divorces in Poland, recognition of foreign judgments, recognition of decisions of foreign authorities in civil matters

a) Dr hab., prof. ALK, Akademia Leona Koźmińskiego. 


\section{Wprowadzenie}

Rozwiązanie małżeństwa na skutek jednostronnego oświadczenia męża (tzw. rozwód przez odrzucenie - talaq), znane prawom państw muzułmańskich, uznawane jest dość powszechnie za niezgodne z kultura prawną Zachodu ${ }^{1}$. Generalnie zastrzeżenia budzą trzy cechy tej postaci rozwodu. Po pierwsze, rozwód talaq - jako instrument, z którego korzystać może tylko mężczyzna - stanowi wyraźną dyskryminację kobiety. Godzi to w zasadę równouprawnienia małżonków. Po drugie, wątpliwości rodzi jednostronny i nieograniczony żadnymi (w zasadzie) przesłankami charakter rozwodów przez odrzucenie per se, tj. w oderwaniu od problemu dyskryminacji kobiet. Innymi słowy, nawet gdyby założyć, że kobieta mogłaby również rozwiązać małżeństwo jednostronnie i bez podania przyczyny, to powstaje pytanie o ocenę takiego rozwodu pod względem zasad znanych w naszym porządku prawnym, w którym rozwód jest sporem stron, a trwałość małżeństwa jest chroniona. Po trzecie wreszcie, zastrzeżenia budzi - choć $\mathrm{w}$ stosunkowo najmniejszym stopniu - pozasądowy charakter rozwodów talaq. Jest on sprzeczny z mocno zakorzenioną w naszym kręgu kulturowym zasadą, że o rozwodzie decyduje sąd w kontradyktoryjnym postępowaniu ${ }^{2}$.

Z uwagi na powyższe rozwody talaq nie są co do zasady akceptowane $\mathrm{w}$ orzecznictwie sądów państw europejskich i innych państw wywodzących się $\mathrm{z}$ europejskiej kultury prawnej. W niektórych okolicznościach rozwody przez odrzucenie były jednak uznawane. Zetknięcia z rozwodem talaq nie można kwitować prostą odmową ich uznania w każdym możliwym przypadku. Należy ponadto odnotować, że prawa państw muzułmańskich ulegają w interesującym nas obszarze ewolucji. Niektóre z nich istotnie zmodyfikowały tradycyjne koraniczne reguły dotyczące rozwodów talaq, co powinno mieć wpływ na ocenę rozwodu przeprowadzonego zgodnie z prawem określonego muzułmańskiego systemu prawnego. $\mathrm{W}$ ocenie piszącego te słowa, również w Polsce możliwe do zaakceptowa-

${ }^{1}$ Zob. zdecydowaną wypowiedź Rzecznika Generalnego Henrika Saugmandsgaarda ØE w opinii z dnia 14 września 2017 r. w sprawie C-372/16 Soha Sahyouni v. Raja Mamisch, ECLI:EU:C:2017:686, pkt 85, 103. Na temat stanowiska Europejskiego Trybunału Praw Człowieka w Strasburgu [dalej: ETPCz] odnośnie do sprzeczności rozwodów talaq z Europejską konwencją o ochronie praw człowieka [dalej: EKPCz] piszę w innym miejscu: M. Zachariasiewicz: Klauzula porzqdku publicznego jako instrument ochrony materialnoprawnych interesów i wartości fori. Warszawa 2018, s. 381 i n.

${ }^{2} \mathrm{O}$ historycznych źródłach tez zasady, ale również pojawiających się współcześnie zastrzeżeniach co do potrzeby jej utrzymywania, zob. np. D. Schwab: Jak małżenstwo trafito do sqdu. „Kwartalnik Prawa Prywatnego” 2017, z. 2, s. 233 i n. 
nia będzie niekiedy uznanie rozwiązania małżeństwa, które nastapiło na podstawie prawa muzułmańskiego, nawet wtedy, gdy chodzi o jednostronny rozwód talaq. Taka decyzja musi być jednak podyktowana szczególnymi okolicznościami, które uzasadniać będą przełamanie sprzeciwu podstawowych zasad naszego porządku prawnego przeciwko jednostronnym rozwodom prawa muzułmańskiego. W niniejszym opracowaniu podejmuję próbę zarysowania kryteriów decydujących o dopuszczalności zaakceptowania rozwodu talaq.

Polskie sądy nie miały, jak dotąd, zbyt często okazji orzekać w sprawach dotyczących rozwodów na gruncie prawa islamskiego. Należy jednak odnotować rozstrzygnięcie Sądu Apelacyjnego w Katowicach z dnia 20 sierpnia 2009 r. $^{3}$, który odmówił uznania jednostronnego rozwodu przez odrzucenie przeprowadzonego pod rządami prawa egipskiego. Orzeczenie to będzie szerzej omawiane w dalszej części opracowania. Również polska doktryna nie wypowiadała się szerzej w tematyce uznawania rozwodów talaq w Polsce ${ }^{4}$. Przedmiotem jej zainteresowania była jednakże niekiedy sama konstrukcja rozwodów w muzułmańskich systemach prawnych ${ }^{5}$ i w kulturze islamu w ogóle ${ }^{6}$.

Zanim przejdziemy do właściwych rozważań poświęconych problemom związanym z uznawaniem rozwodów talaq, należy zwrócić uwagę na wieloznaczność pojęcia „uznanie” w tym kontekście. Zauważmy, że problem takiego „uznania” może powstawać w różnych kontekstach. Najczęściej

${ }^{3}$ I ACa 410/09 [Dostęp: https://orzeczenia.ms.gov.pl].

${ }^{4}$ Rozproszone uwagi na temat uznawania rozwodów talaq w państwach Europy Zachodniej zawarłem w książce: M. Zachariasiewicz: Klauzula..., s. 48, 215, 220, 245-249, 381-383. Na ten temat zob. także: K. Sadowa: Oddziatywanie szariatu na orzecznictwo europejskie i europejski porzadek prawny na przykładzie Niemiec $i$ Wielkiej Brytanii - zarys problematyki. W: „Acta Erasmiana”. T. 7: Z badań nad prawem i administracja. Red. M. Sadowski. Wrocław 2014, s. 125 i n.; J. Pisarek: Stosunek władz Bawarii do mniejszości muzułmańskich. „Studia Oecumenica” 2014, nr 14, s. 269 i n.

${ }^{5} \mathrm{~K}$. Krzysztofek: Dopuszczalność stosowania prawa szariatu w zakresie spraw rozwodowych $i$ spadkowych w prawodawstwie Unii Europejskiej. „Studia z Prawa Wyznaniowego" 2016, vol. 19, s. 26 i n.; M. Sadowski: Matżeństwo w prawie islamu. Poznań 2015, s. 9 i n.; Idem: Rozwód wedtug procedury „talaq” $w$ prawie islamu. „Radca Prawny - Zeszyty Naukowe” 2017, nr 3; Idem: Kontrakt matżeński w prawie islamu. „Studia Prawno-Ekonomiczne” 2017, T. 103, s. 95 i n.; M. Frańczuk: Finanse $w$ matżeństwie muzułmańskim i po jego ustaniu. Porównanie z regulacjami prawa polskiego. „Zeszyty Naukowe Uniwersytetu Ekonomicznego w Krakowie” 2013, nr 901, s. 24; K. Sadowa: Islam religia pokoju czy zagrożeniem dla Europy? Recenzja ksiażki Marka Orzechowskiego „Mój sqsiad islamista. Kalifat u drzwi Europy”. „Wrocławskie Studia Erazmiańskie” 2015, T. 9, s. 634.

${ }^{6}$ A.M. Piwko: Muzutmańskie prawo rodzinne: sposoby rozwiazania matżeństwa w islamie oraz zasady dziedziczenia majatku. „Nurt SVD” 2013, nr 1, s. 204 i n.; Eadem: Rozwód w islamie. „Nurt SVD” 2013 [wyd. specjalne], s. 37 i n.; M. Zekić: Status kobiety w islamskiej teorii i praktyce. „Ways to Religion” 2018, T. 2, s. 251. 
mamy do czynienia z uznaniem orzeczenia zagranicznego sądu lub rozstrzygnięcia innego organu władzy publicznej względnie z uznaniem dokumentu urzędowego jakiegoś rodzaju. Użycie słowa „uznanie” odpowiada w takim wypadku tradycji terminologicznej międzynarodowego postępowania cywilnego. Ponieważ jednak rozwód talaq ma charakter prywatny, a ewentualne działania sądu lub innego organu mają jedynie charakter deklaratoryjny, polski sąd może również stanąć przed koniecznością zastosowania prawa obcego do oceny skuteczności rozwodu talaq dokonanego przez męża, w braku jakichkolwiek rozstrzygnięć obcych organów czy dokumentów przez nie wydanych. W takim wypadku określenia „uznanie" używamy jedynie jako skrótu myślowego. W istocie nie chodzi tu bowiem o uznanie, lecz o stosowanie prawa obcego (i ewentualną odmowę jego stosowania na podstawie klauzuli porządku publicznego).

\section{Muzułmańskie rozwody talaq}

Rozwód talaq stanowi tradycyjna postać rozwiązania małżeństwa pochodzaca z prawa koranicznego? ${ }^{7}$. Istotą takiego rozwodu jest jednostronna, w dużej mierze dyskrecjonalna, decyzja mężczyzny. Kobieta bądź w ogóle nie ma prawa opierać się takiemu rozwodowi, bądź jej uprawnienia sa bardzo ograniczone ${ }^{8}$. Kobiecie nie przysługuje też analogiczne uprawnienie do jednostronnego rozwiązania małżeństwa ${ }^{9}$. W klasycznej postaci (w dużej mierze zachowanej do dzisiaj) dla skuteczności rozwodu wystarczy trzykrotne wypowiedzenie przez męża słów: „rozwodzę

${ }^{7} \mathrm{~W}$ państwach muzułmańskich prawo religijne (prawo szariatu) jest źródłem powszechnie obowiąującego prawa rodzinnego. Także w państwach muzułmańskich, w których prawo rodzinne zostało poddane istotnym reformom i w których przyjęto nowe kodeksy prawa rodzinnego, tradycyjne zasady prawa religijnego miały znaczny wpływ na ich kształtowanie. Zob. M. Sadowski: Matżeństwo..., s. 9 i n.; K. Krzysztofek: Dopuszczalność..., s. 25. Na temat rozwodu w Koranie zob. A.M. Piwko: Muzułmańskie..., s. 205 i n.

${ }^{8}$ Por. np. M. Enright: The Beginning of the Sharpness: Loyalty, Citizenship and Muslim Divorce Practice. „International Journal of Law in Context” 2013, vol. 9, no. 3, s. 1 i n.; I. Isailovic: La reconnaissance politique en droit transnational: les identités, les marginalisations et le droit international privé. In: Droit international et reconnaissance. Eds. H. Muir Watt, E. Tourme Jouannet. Paris 2015, przyp. 19; S. Vrellis: Conflit ou coordination de valeurs en droit International privé. „Receuil des Cours” 2007, vol. 328 , s. 301.

${ }^{9}$ H. Kr üger: Prawo matżeńskie $i$ spadkowe $w$ dzisiejszym świecie orientalnym. „Problemy Prawa Prywatnego Międzynarodowego” 2016, T. 19, s. 122. 
się z Tobą",,odrzucam Cię" (talaq, talaq, talaq) ${ }^{10}$. Jest to jednostronne oświadczenie woli mężczyzny. Słowa te moga być sformułowane ustnie lub na piśmie. Tradycyjnie często miało to miejsce w liście rozwodowym. W niektórych państwach muzułmańskich za wystarczające uważa się wysłanie oświadczenia rozwodowego w formie SMS-a ${ }^{11}$ lub wpis na Facebooku ${ }^{12}$. Dla złożenia oświadczenia o odrzuceniu żony niekiedy wymaga się udziału świadków. W świetle przepisów niektórych państw muzułmańskich żona nie musi być nawet zawiadamiana o rozwodzie. Może w konsekwencji w ogóle nie wiedzieć, że jej małżeństwo zostało przez męża rozwiązane ${ }^{13}$.

Dla skuteczności rozwodu przez odrzucenie nie jest najczęściej konieczne orzeczenie sądu ani udział innego organu władzy publicznej ${ }^{14}$. Małżeństwo w prawie muzułmańskim ma wszakże silnie kontraktowy charakter ${ }^{15}$. Podobnie zatem jak w ramach prawa umów, udział organu nie jest niezbędny do rozwiązania istniejącego stosunku prawnego. Dokonuje się to na podstawie oświadczenia woli. $\mathrm{Z}$ reguły możliwe jest wszakże - a w świetle praw niektórych państw muzułmańskich także wymagane - uzyskanie potwierdzenia skuteczności przeprowadzonego rozwodu przez sąd lub inny organ, np. notariusza publicznego. Decyzja organu ma najczęściej charakter deklaratoryjny. Gdzieniegdzie urzędowa rejestracja rozwodu jest jednak obowiązkowa i może wpływać na jego skutecznośćc ${ }^{16}$. Niekiedy wymagane jest także przeprowadzenie procedury koncyliacyjnej między małżonkami ${ }^{17}$.

10 Zob. np. S.D. Nader: Twenty Years After Gutierrez v. Collins: Public Policy And Conflict Of Laws Analysis In Texas Tort Cases. „Baylor Law Review” 2000, vol. 52, s. 225; P. Fournier: Please divorce me! Subversive agency, resistance and gendered religious scripts. In: Muslim Family Law in Western Courts. Ed. E. Giunchi. Abingdon 2014, s. 36; J. O'Brien: Conflict of Laws. $2^{\text {nd }}$ ed. London 1999, s. 483.

${ }^{11}$ Tak np. w prawie Zjednoczonych Emiratów Arabskich. Zob. K. Krzysztofek: Dopuszczalność..., s. 26.

${ }^{12}$ M. Sadowski: Rozwód..., s. 49.

${ }_{13}$ Zob. angielskie orzecznictwo omawiane przez Al-R. Moosa, D. Helly: An analysis of British judicial treatment of Islamic divorces 1997-2009. In: Muslim Family Law..., Ed. E. Giunchi, s. 134 i n.

${ }^{14}$ S. Vrellis: Conflit..., s. 301; K. Krzysztofek: Dopuszczalność..., s. 26; J. O’Brien: Conflict..., s. 483; Al-R. Moosa, D. Helly: An analysis..., s. 131.

${ }_{15}$ A. Büchler, A. Latif: Judicial encounters with Islamic and Middle Eastern family law in Switzerland from a private international law perspective - marriage and divorce. In: Muslim Family Law..., Ed. E. Giunchi, s. 79; I. Bantekas: Transnational Talaq (Divorce) In English Courts: Law Meets Culture. „Journal of Islamic State Practice in International Law" 2013, no. 2, s. 42. Por. M. Sadowski: Rozwód..., s. 40; Idem: Kontrakt..., s. 95 i n.; M. Frańczuk: Finanse..., s. 20.

16 Taka sytuacja ma miejsce w Egipcie.

${ }^{17}$ Taki wymóg zna np. prawo pakistańskie. Zob. J. O’Brien: Conflict..., s. 483. 
Kobieta, która zostaje odrzucona przez męża, uprawniona jest do zachowania podarunku, wręczanego przez narzeczonego $\mathrm{w}$ chwili zawierania małżeństwa (mahr). Mahr jest własnością żony. Gdy mąż postanawia się z nią rozwieść, żona może zachować mahr dla siebie. Płatność mahru lub określonej jego części może też być odroczona do chwili rozwodu (tj. mąż jest zobowiązany wypłacić przyobiecany wcześniej mahr, gdy chce się rozwieść $)^{18}$. Wartościowy mahr służy jako czynnik zniechęcający męża od rozwodu i tym samym wzmacniający więź małżeńską ${ }^{19}$. Zabezpiecza jednocześnie kobietę finansowo po ustaniu małżeństwa ${ }^{20}$. Wskazuje się, że jest to jedno z podstawowych uprawnień żony w małżeństwie zawartym na podstawie prawa szariatu ${ }^{21}$.

Prawa państw muzułmańskich znaja również inne niż talaq postaci rozwodu, w tym dostępne dla kobiet (khul, faskh). Kobiety nie maja jednak uprawnień analogicznych do przysługujących mężczyznom w ramach rozwodu talaq. Uzyskanie przez nie rozwodu jest znacznie trudniejsze i co do zasady implikuje ocenę określonych przesłanek przez sąd lub inny organ ${ }^{22}$. Mężczyzna może się sprzeciwiać rozwodowi, którego domaga się kobieta ${ }^{23}$. Kobieta wnosząca o rozwód traci ponadto uprawnienie do wypłaty na jej rzecz mahru ${ }^{24}$.

Należy pamiętać, że współcześnie kodeksy rodzinne wielu państw islamskich ulegały ewolucji ${ }^{25} \mathrm{i}$ w konsekwencji różnią się od siebie co do przyjmowanych form rozwodu przez odrzucenie ${ }^{26}$. Z reguły dochodzi wszelako do jakiegoś uprzywilejowania mężczyzny ze szkodą dla kobiety ${ }^{27}$.

18 Zob. H. Krüger: Prawo..., s. 120; A. Kozioł, w: Prawo prywatne międzynarodowe. Komentarz. Red. M. Pazdan. Warszawa 2018, s. 503; M. Frańczuk: Finanse..., s. 24.

${ }^{19}$ P. Fournier: Please..., s. 36-37.

${ }^{20}$ M. Frańczuk: Finanse..., s. 24; M. Sadowski: Kontrakt..., s. 107.

${ }^{21}$ K. Sadowa: Oddziatywanie..., s. 129.

${ }^{22}$ H. Krüger: Prawo..., s. 122.

${ }^{23}$ Al-R. Moosa, D. Helly: An analysis..., s. 131.

${ }^{24}$ P. Fournier: Please..., s. 35, 45.

${ }^{25} \mathrm{Na}$ przykład stosunkowo niedawno kodeksy rodzinne przyjęte zostały w Maroku (2004), Katarze (2006), Zjednoczonych Emiratach Arabskich (2005) czy Etiopii (2000). Z kolei w Indiach Sąd Najwyższy orzekł ostatnio (22.08.2018 r.), że rozwody talaq (praktykowane przez muzułmańską społeczność tego kraju) są niezgodne z indyjską konstytucja. Zob. https://www.theguardian.com/world/2017/aug/22/india-supreme-court-bansislamic-instant-divorce-triple-talaq [Dostęp: 2.06.2020 r.].

${ }^{26}$ Zob. np. na temat różnych form znanych w prawie marokańskim J.-Y. Carlier, C. Henricot: Belgique, de l'exception d'ordre public aux accomodements réciproques? „Cahiers du CEDIE working papers” 2011, no. 3, s. 26.

${ }^{27}$ K. Krzysztofek: Dopuszczalność..., s. 25. 


\section{Doktryna i praktyka orzecznicza dotycząca uznawania rozwodów talaq w innych państwach}

W państwach Europy Zachodniej, jak również w USA i Kanadzie gdzie obecna jest duża społeczność muzułmańska — sądy stosunkowo często stawały przed koniecznością stosowania lub przynajmniej uwzględniania muzułmańskiego prawa wywodzącego się z religijnego sharia, w tym w przedmiocie rozwodów talaq. Zagadnienie uznawania rozwodów przeprowadzonych pod rządami prawa muzułmańskiego jest też żywo dyskutowane $\mathrm{w}$ doktrynie. Jak zasygnalizowano już na wstępie, rozwody talaq budzą zastrzeżenia z trzech głównych powodów: stanowią naruszenie zasady równouprawnienia kobiety i mężczyzny w małżeństwie, budzą wątpliwości z uwagi na swój jednostronny i dyskrecjonalny charakter (nawet w oderwaniu od problemu dyskryminacji kobiet) oraz z powodu prywatnego, pozasądowego charakteru. W konsekwencji, rozwody talaq rodza silny sprzeciw w praktyce orzeczniczej i doktrynie państw europejskiej kultury prawnej. Na podstawie klauzuli porządku publicznego sądy najczęściej odmawiają ich uznania (gdy przeprowadzone zostały w państwie muzułmańskim pod rządami prawa tam obowiązującego i zarejestrowane przez sąd lub inny organ władzy publicznej) ${ }^{28}$ bądź odmawiaja stosowania obcego prawa właściwego, przewidującego taki rozwód. Ponieważ ten pierwszy rodzaj przypadków jest w praktyce zdecydowanie częstszy, poniżej będziemy mówić przede wszystkim o „uznawaniu rozwodów talaq" stwierdzonych przez orzeczenie lub inne rozstrzygnięcie pochodzące od organu władzy publicznej w państwie muzułmańskim ${ }^{29}$.

${ }^{28}$ Zob. we Francji: Cass. civ., 4.11.2009. „Revue Critique de Droit International Privé” 2010, s. 313; Cass. civ., 28.11.2006. „Revue Critique de Droit International Privé” 2006, s. 584; Cass. civ., 17.02.2004, D. 2004, s. 824 (pięć orzeczeń Cour de Cassation, wydanych w tym samym dniu w podobnych sprawach); Cass. civ., 14.03.2002. JCP 2002, II, 10095; Cass. civ., 12.07.2001. „Bulletin civil” I, no 218; Cass civ. 1.06.1994. „Revue Critique de Droit International Privé” 1995, s. 103; Dahar, Cass. civ., 18.12.1979. D. 1980, s. 550; w Anglii: A v. L [2010] EWHC 460; R v Secretary of State for the Home Department ex p Ghulam Fatima [1986] AC 527; Chaudhary v. Chaudhary [1984] 3 All ER 1017; w Niemczech: OLG Stuttgart, 3.12.1998, 17 VA 6/98; AG Frankfurt/Main, 9.08.1988, 35 F 4153/87; OLG Stuttgart, 11.04.1987, 1VA 5/86; LJV Baden-Württemberg, 23.05.1986 - 346E-325/85 (niem. orzecznictwo cyt. za: P. Fournier: The reception of Muslim family laws in western liberal states. „Women Living Under Muslim Law Dossier” 2005, vol. 27, s. 72); w Szwajcarii: Tribunal Fédéral, 8.02.1962, 88 I 48; w Grecji: orz. sądu w Thessalonikach z 19.12.2017 [niepubl.]; w USA: Aleem v. Aleem, 947 A.2d 489 (Md. 2008); Seth v. Seth, 694 S.W.2d 459, 463 (Tex. App.-- Fort Worth 1985).

${ }^{29} \mathrm{Z}$ reguły chodzi wszakże o uznanie orzeczenia sądu lub rozstrzygnięcia innego organu, które stwierdzają rozwód talaq. Z taką sytuacją mamy także do czynienia na tle glosowanego postanowienia Sąu Apelacyjnego w Katowicach. 
Nie oznacza to jednak, że rozwody talaq nigdy nie są i nie moga być uznawane w Europie. Istnieje kilka rodzajów okoliczności, które zdaniem organów orzekających mogą uzasadniać uznanie rozwodu talaq. Przedstawiam je poniżej, dokonując podziału na kilka kategorii.

Pierwszym czynnikiem, który może usprawiedliwiać uznanie rozwodu talaq, sa słabe powiązania stanu faktycznego sprawy z forum. W wielu porządkach prawnych przyjmuje się w orzecznictwie i doktrynie, że nikłe związki stanowia przesłankę ograniczajacca działanie klauzuli porządku publicznego ${ }^{30}$. Zasadniczą okolicznością wydaje się przy tym miejsce zamieszkania/zwykłego pobytu małżonków w chwili przeprowadzania rozwodu. Jeśli znajdowało się ono na terytorium państwa muzułmańskiego znającego rozwód przez odrzucenie, a kwestia uznania tego rozwodu w państwie europejskim wypłynęła później (z reguły ponieważ jeden z małżonków przeniósł centrum swoich życiowych interesów na teren tego drugiego państwa), to często przyjmowano, że rozwód talaq może być uznany. Nawet okoliczność, że chodziło o osoby, które uzyskały obywatelstwo państwa europejskiego, mogła nie stanowić wystarczającego powodu dla ingerencji za pomocą klauzuli porządku publicznego przeciwko takiemu rozwodowi. Jednocześnie jednak należy podkreślać, że uznanie rozwodu uzasadniały często - poza słabymi związkami z forum - także inne okoliczności sprawy (o których mowa będzie niżej).

Brak bliższych związków sprawy z forum uzasadniał uznanie rozwodów talaq m.in. w Anglii ${ }^{31}$. I tak w wyroku w sprawie El Fadl v. El Fadl ${ }^{32}$ angielski sąd zaakceptował rozwód przez odrzucenie, przeprowadzony zgodnie z prawem libańskim, ponieważ strony zamieszkiwały - w chwili rozwodu — w Libanie. W momencie rozwodu brak było też innych, zna-

${ }^{30}$ Chodzi o przesłankę stosowania klauzuli, określaną w literaturze zagranicznej jako Inlandsbeziehung (Niemcy), ordre public de proximité (Francja) lub proximity (Anglia). W swych publikacjach zaproponowałem, aby używać tu określenia „związek z forum”. Zob. szerzej M. Zachariasiewicz: Klauzula..., s. 200 i n. W literaturze obcej zob. np. P. Lagarde: Public Policy (chapter 11). In: International Encyclopedia of Comparative Law. Vol. 3: Private International Law. Part 1. Ed. K. Lipstein. Tübingen 1986, s. 38-39; Idem: Recherches sur l'ordre public en droit international privé. Paris 1959, s. 58; A. Fiorini: The Codification of Private International Law: The Belgian Experience. „International Comparative Law Quarterly” 2005, vol. 54, s. 515; N. Joubert: La notion de liens suffisants avec l'ordre juridique (Inslandsbeziehung) en droit international privé. Paris 2007, s. 3 i n.

${ }^{31} \mathrm{~W}$ Anglii wydaje się to o tyle łatwiejsze, że istnieje wyraźny przepis nakazujący uznawanie rozwodów, jeśli są one skuteczne w świetle prawa państwa pochodzenia (choć oczywiście prawo zezwalana na odmowę uznania rozwodu w razie naruszenia zasad porząlku publicznego - public policy). Zob. Family Law Act 1986, sec. 46(a). W literaturze zob. na ten temat Al-R. Moosa, D. Helly: An analysis..., s. 132 i n.

${ }^{32}$ El Fadl v. El Fadl [2000] 1 FLR 175. 
czących związków pary z Anglia. Podobnie w wyroku w sprawie $H v \cdot H^{33}$ sąd uznał rozwód talaq uzyskany zgodnie z prawem pakistańskim, mimo że chodziło o małżeństwo obywateli brytyjskich. Sąd podkreślił jednak, że para małżeńska zachowała bliskie więzi z Pakistanem, a rozwód nastąpił dwadzieścia lat wcześniej.

Także sąd rodzinny w Quebecu, w starannie uzasadnionym orzeczeniu z 2007 r., wyraził gotowość uznania rozwodu talaq ${ }^{34}$. Sąd podniósł, że przy całkowitym braku powiązań stanu faktycznego z Quebekiem (rozwód talaq miał miejsce pomiędzy małżonkami mającymi w chwili rozwodu miejsce zamieszkania $\mathrm{w}$ państwie islamskim i obywatelami takiegoż państwa) interwencja klauzuli porządku publicznego nie jest konieczna $^{35}$. W ocenie sądu okoliczność, że żona zamieszkiwała w Kanadzie $\mathrm{w}$ chwili rozstrzygania o uznaniu rozwodu nie stanowiła relewantnego związku sprawy z forum ${ }^{36}$.

Również w Norwegii przyjmuje się, że rozwód talaq jest sprzeczny z lokalnym porządkiem publicznym tylko wtedy, gdy rozwód jest powiązany z terytorium Norwegii za pomoca istotnych okoliczności faktycznych, w szczególności przez miejsce zamieszkania małżonków lub jednego $\mathrm{z}$ nich ${ }^{37}$. Jeżeli natomiast rozwód nastąpił zanim małżonek wnoszący o uznanie rozwodu osiedlił się w Norwegii, co do zasady podlega on uznaniu w tym państwie ${ }^{38}$.

Gotowość do uznania rozwodu w braku istotnych związków sprawy $\mathrm{z}$ forum można także zaobserwować w judykaturze francuskiej. W kraju tym nastapiła jednak istotna ewolucja praktyki orzeczniczej. Wymaga to kilku słów wyjaśnienia. Począwszy od lat pięćdziesiątych ubiegłego wieku rozwody talaq uznawane były na podstawie koncepcji powściągliwego

${ }^{33}$ H v. H [2007] EWHC 2945 (Fam).

${ }^{34}$ Orz. Cour supérieure du Québec, Droit de la famille — 072464, 2007 QCCS 482, http://citoyens.soquij.qc.ca.

${ }^{35}$ Warto jednak zwrócić uwagę, że pogląd ten stanowił jedynie obiter dictum. In concreto sąd i tak nie uznał orzeczenia z państwa islamskiego, ponieważ ustalił, że mąż nadużył procedury rozwodowej (mąż żył wspólnie i współżył z żoną jeszcze po jej odrzuceniu za pomoca procedury talaq; zgodnie z prawem muzułmańskim, w normalnym toku rzeczy takie działanie odwołuje rozwód; na skutek fałszywych zeznań w postępowaniu w państwie islamskim uzyskał on jednak potwierdzenie rozwodu). Gotowość montrealskiego sądu uznania rozwodu talaq była zatem jedynie teoretyczna.

${ }^{36} \mathrm{Z}$ tego powodu rozumowanie montrealskiego sądu krytycznie ocenia G. Goldste in: The Recognition and Enforcement of Foreign Decisions in Québec. „Yearbook of Private International Law" 2013/2014, vol. 15, s. 309.

${ }^{37}$ K.J. Fredriksen: The recognition of transnational Muslim marriages and divorces by Norwegian courts and other competent authorities: dynamics between legislation and legal practice. In: Muslim Family Law..., Ed. E. Giunchi, s. 102.

38 Ibidem. 
stosowania klauzuli porządku publicznego (l'effet attenué) ${ }^{39}$. Koncepcja l'effet attenué wypracowana została przez francuski Cour de Cassation w orzeczeniu z $1953 \mathrm{r}$. w sprawie Rivière ${ }^{40}$. Zgodnie z tym precedensowym wyrokiem, „reakcja przeciwko regule, która jest sprzeczna z porządkiem publicznym, nie jest taka sama w sytuacji, w której uniemożliwia ona nabycie prawa we Francji, jak w przypadku, w którym chodzi raczej o uznanie we Francji skutków prawa nabytego na obcym terytorium na podstawie prawa właściwego zgodnie $\mathrm{z}$ francuskim prawem prywatnym międzynarodowym, o ile nie zachodzi obejście prawa [tłum. M.Z.]”14. Prowadzaca do uznania rozwodu talaq analiza przebiega zatem następująco: rozwód, który miał miejsce za granica, zgodnie z obcym prawem właściwym, na podstawie normy kolizyjnej forum, nastapił w określonym oddaleniu; na obecnym etapie chodzi jedynie o uznanie skutków, które już wystąpiły pod rządami obcego prawa, w szczególności zaś polegające na ustaniu małżeństwa; rozwód stanowi zdarzenie zagraniczne i jako takie co do zasady jest uprawnione, aby być uznane na terenie Francji. Oddalenie rozwodu talaq, będące zdarzeniem stanowiącym przyczynę ustania stosunku małżeństwa, które nastąpiło na terenie obcego państwa, w określonej przeszłości, stanowi drugi rodzaj okoliczności, który może (potencjalnie) uzasadniać uznanie rozwodu talaq.

Nie budzi wattpliwości, że koncepcja l'effet attenué była niekiedy we Francji nadużywana. Imigranci pochodzący z państw muzułmańskich na stałe osiadli we Francji powracali na krótko do swego kraju pochodzenia, gdzie przeprowadzali rozwód przez odrzucenie żony (często chodziło nawet o małżeństwa zawarte we Francji) ${ }^{42}$. Tam też rozwód ten rejestrowali, następnie domagając się jego uznania we Francji, argumentując,

${ }^{39}$ Zob. orz. w spr. Rohbi, Cass. civ. 3.11.1983. „Revue Critique de Droit International Privé" 1984, s. 325. W literaturze na ten temat zob. A. Sinay-Cytermann: Les tendances actuelles de l'ordre public international. In: Mélanges en l'honneur du Professeur Bernard Audit: Les relations privées internationals. Paris 2014, s. 639; P. Lagarde: Public Policy..., s. 41.

${ }^{40}$ Rivière, Cass. civ. 17.04.1953. „Revue Critique de Droit International Privé” 1953, s. 412. Zob. również obszerne omówienie tego orzeczenia i kontekstu, w jakim ono zapadło: A. Gavalda: Remarques sur l'arrêt Rivière. „Travaux du Comité français de droit international privé" 1955, vol. 14, s. 115-148. Warto wyjaśnić, że w wyr. w sprawie Rivière nie chodziło o rozwody talaq. Koncepcja l'effet attenué wypracowana w tym orzeczeniu wykorzystywana była jednak później do ich uznawania we Francji.

${ }^{41} \mathrm{Na}$ temat wyr. w sprawie Rivière i koncepcji l'effet attenué zob. szerzej M. Zachariasiewicz: Klauzula..., s. 241 i n.

${ }^{42}$ Istnieją doniesienia, zgodnie z którymi podobna praktyka jest znana także na naszym obszarze prawnym. Zob. M. Sadowski: Kontrakt..., s. 96, który na podstawie kwerendy przeprowadzonej we wrocławskim USC ustalił, że „niektórzy muzułmanie po uzyskaniu obywatelstwa polskiego wyjeżdżają do swojego kraju, aby tam przeprowadzić procedurę rozwodową w oparciu o szariat". 
że rozwiązanie małżeństwa nastapiło w wystarczającym oddaleniu, aby uzasadnić nieingerencję francuskiego porządku publicznego. Przypadki takie określano jako voyage de répudiation („podróż w celu odrzucenia" ${ }^{43}$. Francuskie sądy często godziły się uznawać rozwody talaq, nawet w przypadkach, gdy zachodziły tego typu okoliczności.

Należy zwrócić uwagę, że w latach 2001-2004 nastąpiła istotna zmiana orzecznictwa dotyczącego rozwodów przez odrzucenie. Zamiast analizy na podstawie koncepcji powściągliwej ingerencji porządku publicznego, Cour de Cassation oparł się bowiem na badaniu stopnia powiązania stanu faktycznego $\mathrm{z}$ forum. W kilku orzeczeniach (z lat $2001^{44}, 2002^{45}$ i $2004^{46}$ ) przyjął on, że jeżeli małżonkowie, lub chociaż żona, mają miejsce zamieszkania we Francji, to ingerencja francuskiego porządku publicznego przeciwko rozwodom talaq jest uzasadniona. W przeciwnym jednak wypadku — gdy żadne z małżonków nie ma miejsca zamieszkania we Francji, uznanie rozwodu talaq nie jest wykluczone.

Trzecia już okolicznością, która może uzasadniać uznanie rozwodu talaq, jest potrzeba uwzględniania dalszych skutków życiowych, które nastąpiły pomiędzy odrzuceniem żony a chwilą, w której o kwestii uznania takiego rozwodu rozstrzyga sąd w kraju europejskim. Uznanie rozwodu przez odrzucenie może być uzasadnione w celu przeciwdziałania zjawisku kulejacych małżeństw, tj. małżeństw skutecznych w świetle prawa określonego państwa, ale nieskutecznych w świetle prawa innego państwa (limping marriages) ${ }^{47}$. Jest to oczywiście bardzo niekorzystna sytuacja, ponieważ powstaje dualizm prawny w obszarze praw i obowiazków małżonków ${ }^{48}$. Nadto, uznanie rozwodu talaq może być usprawiedliwione $\mathrm{w}$ celu zapobiegania próbom wykorzystania argumentu o bezskuteczności rozwodu talaq do podważenia ważności kolejnego małżeństwa (jako bigamicznego), zawartego przez jedna ze stron tego rozwodu w szczególności przez odrzuconą żonę.

Za dobry przykład służy w omawianym obszarze orzeczenie Sądu Apelacyjnego w Cagliari (Włochy) z 2008 r. ${ }^{49}$ Małżeństwo zawarte w Egipcie

${ }^{43}$ A. Sinay-Cytermann: Les tendances..., s. 639-640.

${ }^{44}$ Cass. civ., 12.07.2001. „Bulletin civil” I, no 218.

${ }^{45}$ Cass. civ., 14.03.2002. JCP 2002, II, 10095.

${ }^{46}$ Cass. civ., 17.02.2004. „Receuil Dalloz” 2004, s. 824 (pięć orzeczeń wydanych $\mathrm{w}$ tym samym dniu w podobnych sprawach).

${ }^{47} \mathrm{Na}$ temat małżeństw kulejących w kontekście małżeństw dzieci zob. ostatnio: E. Kamarad: Kolizyjnoprawne aspekty matżeństw dzieci. „Problemy Prawa Prywatnego Międzynarodowego” 2019, vol. 24, s. 90. W kontekście odmowy uznania rozwodów przeprowadzonych na podstawie prawa muzułmańskiego zob. np. K.J. Fredriksen: The recognition..., s. 92 .

${ }^{48}$ Ibidem.

${ }^{49}$ CA Cagliari (Włochy), 16.05.2008 [opubl. w jęz. franc. w JDI 2013, nº 2]. 
zostało rozwiązane przez odrzucenie już po dwóch latach, co stwierdził wyrokiem sąd w Egipcie. Rozwodnicy wstąpili w nowe związki małżeńskie, z których mieli dzieci. W międzyczasie mąż przeniósł się do Włoch i otrzymał włoskie obywatelstwo. O uznanie egipskiego orzeczenia rozwodowego wystapiono we Włoszech 13 lat później. W tej sytuacji włoski sąd przyjął, że sytuacja faktyczna skrystalizowała się wystarczająco, aby uzasadnić nieingerencję w skuteczność rozwodu przeprowadzonego pod rządami egipskiego prawa wiele lat wcześniej. Wymagało tego poszanowanie nowych związków małżeńskich.

Rozwód talaq został również uznany przez sąd angielski w sprawie Wicken v. Wicken ${ }^{50}$. Rozwód przeprowadzono w Gambii pomiędzy obywatelami tego państwa. Odrzucona żona zawarła następnie w Anglii nowe małżeństwo. Spór o skuteczność rozwodu talaq powstał, gdy kobieta wystąiła o rozwód jej drugiego małżeństwa, a mąż (drugi) podniósł zarzut jego wadliwości z powodu bigamii (decree of nullity). Skoro bowiem pierwsze małżeństwo nie zostało skutecznie rozwiązane, to skuteczność drugiego mogłaby być kwestionowana. Sąd zdecydował jednak uznać rozwód talaq, co oznaczało w konsekwencji, że drugie małżeństwo jest w pełni skuteczne i może być rozwiązane co najwyżej przez rozwód.

Czwartym powodem przemawiającym za uznaniem rozwodu talaq jest zapewnienie kobiecie wystarczających gwarancji procesowych $\mathrm{w}$ toku rozwodu. Nie zawsze bowiem rozwód talaq odbywa się pozasądownie i całkowicie jednostronnie. Niektóre jego formy stwarzają kobiecie określone możliwości opierania się rozwodowi. Z tego typu przypadkiem miał do czynienia sąd w Teksasie w sprawie Ashfaq v. Ashfaq ${ }^{51}$. W wyroku z 2015 r. sąd uznał rozwód talaq przeprowadzony w Pakistanie. Procedura rozwodowa była tu wprawdzie $\mathrm{w}$ dużej mierze jednostronna, ale żona została zawiadomiona o jej wszczęciu. Ponadto, wymagany był dziewięćdziesięciodniowy okres, podczas którego specjalna rada arbitrażowa podejmowała próbę koncyliacji pomiędzy małżonkami. Teksaski sąd stwierdził, że uznanie rozwodu talaq $\mathrm{w}$ takich okolicznościach nie narusza porządku publicznego. Podobne rozstrzygnięcie zapadło w Anglii w sprawie Quazi v. Quazi, gdzie chodziło o uznanie rozwodu przeprowadzonego w analogicznej procedurze w Pakistanie ${ }^{52}$. W doktrynie anglosaskiej określa się tego typu rozwód jako „formalny/procesowy talaq” (formal/procedural talaq), w przeciwieństwie do „zwykłego talaq” (bare talaq), w ramach którego brak jest jakiegokolwiek postępowania przed

50 Wicken v. Wicken (1999) Fam 224.

${ }^{51}$ Ashfaq v. Ashfaq, 467 S.W. 3d 539 (Tex. App. 2015).

52 [1980] AC 744. 
sądem lub innym organem ${ }^{53}$. Sama obecność świadków przy składaniu oświadczenia o rozwodzie nie jest jednak wystarczająca, aby można było mówić o „postępowaniu rozwodowym” ${ }^{54}$.

Podobnie francuski Cour de Cassation w wyroku z 2001 r. ${ }^{55}$ zaakceptował rozwód przez odrzucenie przeprowadzony w Algierii, ponieważ ustalił, że żona mogła przedstawić swoje stanowisko przed sądem, oraz że zapewniono jej gwarancje procesowe w postępowaniu rozwodowym.

Piąta okolicznością, która łagodzi ostrze klauzuli porządku publicznego interweniujacej przeciwko rozwodom talaq, jest finansowe zabezpieczenie odrzucanej żony. Jeżeli prawa kobiety sa w tym przedmiocie wystarczająco zagwarantowane, to może to stanowić dodatkowy argument przemawiajacy za zaakceptowaniem rozwodu, nawet jeżeli miał on charakter jednostronny. Interes majątkowy kobiety może być w szczególności zabezpieczony przez odpowiednio wysoka wartość daru małżeńskiego (mahr). Przesadziło to o uznaniu rozwodu talaq przez są szwedzki ${ }^{56}$. Również w angielskim orzeczeniu $\mathrm{El} \mathrm{Fadl} v$. El Fadl ${ }^{57}$ fakt zabezpieczenia finansowego odrzuconej żony wydawał się mieć wpływ na uznanie rozwodu talaq. W sprawie tej mąż utrzymywał eksżonę finansowo 16 lat po jej odrzuceniu. Sprawa uznania rozwodu talaq zawisła w angielskim sądzie dopiero wtedy, gdy mąż zaprzestał utrzymywania eksżony. Kobieta zakwestionowała wtedy skuteczność rozwodu talaq. Argument finansowy nie był tu jednak jedynym przemawiajacym za uznaniem rozwodu (brak było również ścisłych więzi sprawy z Anglią — zob. wyżej).

Z kolei brak adekwatnego zabezpieczenia finansowego odrzucanej żony stanowi najczęściej argument przeciwko zaakceptowaniu rozwodu talaq. Podkreślił to francuski Cour de Cassation w wyroku z 2006 r., odmawiając zastosowania właściwego dla rozwodu prawa marokańskiego $^{58}$. Jednak zdaniem belgijskiego Cour de Cassation, brak alimentów dla żony na wypadek rozwodu nie jest wystarczającym argumentem za ingerencją klauzuli porządku publicznego przeciwko jego skuteczności ${ }^{59}$.

${ }^{53}$ Zob. S. Symeonides: Choice of Law in the American Courts in 2015: Twenty-Ninth Annual Survey. „American Journal of Comparative Law” 2016, vol. 64, s. 68; J. O'Brien: Conflict..., s. 476.

${ }^{54}$ Chaudhary v. Chaudhary [1985] Fam 19.

${ }_{55}$ Cass civ., 3.07.2001. „Bulletin civil” 2001 I, n 199, s. 127.

${ }^{56}$ Gdyby sąd odmówił zastosowania prawa właściwego dopuszczającego rozwód talaq, stosując w to miejsce prawo szwedzkie, kobieta utraciłaby mahr. Podaję za K. Krzysztofek: Dopuszczalność..., s. 32.

${ }^{57}$ El Fadl v. El Fadl [2000] 1 FLR 175.

${ }^{58}$ Cass civ., 28.11.2006. „Revue Critique de Droit International Privé” 2006, s. 584.

${ }^{59}$ Cour de Cassation, 18.06.2007, $\mathrm{n}^{\circ}$ C.06.0116.F. Orzeczenie spotkało się z krytyka w doktrynie. Zob. J.-Y. Carlier: Quand l'ordre public fair désordre. „Tijdschrift voor Belgisch Burgerlijk Recht”2008, no. 9, s. 526. 
Wreszcie ostatnią, szóstą już, okolicznością, która uzasadnia zaakceptowanie rozwodu talaq, jest zgoda kobiety ${ }^{60}$. Zgoda ta może zostać wyrażona w trakcie rozwodu, w szczególności jeśli odbyło się jakieś postępowanie rozwodowe, ale także na późniejszym etapie. Przyjmuje się, że jeżeli kobieta występuje $\mathrm{z}$ wnioskiem o uznanie rozwodu talaq, to należy to traktować jako jej zgodę na rozwód ${ }^{61}$. Jest jednak oczywiste, że zgoda musi zostać wyrażona świadomie i swobodnie. Są rozstrzygajaccy o uznaniu rozwodu talaq powinien to zweryfikować, zwłaszcza gdy mąż podnosi, że zgoda kobiety została wyrażona w toku postępowania rozwodowego $\mathrm{w}$ państwie muzułmańskim. Znane sa także przypadki, w których sąd europejski zaakceptował rozwód talaq po złożeniu stosownego oświadczenia przez męża bezpośrednio przed tym sądem, a żona wyraziła zgodę na rozwód ${ }^{62}$. Nawet jednak wyraźna zgoda kobiety, w tym wyrażona przez wniesienie wniosku o uznanie rozwodu talaq w Europie, może okazać się niewystarczającym argumentem za jego zaakceptowaniem. Uznania rozwodu talaq odmówił ostatnio sąd w Thessalonikach, mimo że wnioskowała o to eksżona ${ }^{63}$. Stanowisko greckiego sądu jest przykładem kategorycznego - i nie zawsze słusznego in concreto - sprzeciwu wobec rozwodów przez odrzucenie, podkreślającego ich sprzeczność z podstawowymi zasadami porządku publicznego państwa europejskiej kultury prawnej ${ }^{64}$.

${ }^{60}$ Zob. np. A. Büchler, A. Latif: Judicial..., s. 73 i n., którzy omawiają ewolucję szwajcarskiej judykatury w tym względzie.

${ }^{61}$ Zob. A. Anthimos: Talaq v Greek public policy: Operation successful, patient dead..., 3.08.2018, conflictoflaws.net; Idem: No recognition of an Egyptian talaq on public policy grounds. „International Civil Litigation in Greece”, 3.08.2018, icl-in-greece. blogspot.com.

${ }^{62}$ AG Esslingen, 19.03.1992, 1F 162/92 (cyt. za: P. Fournier: The reception..., s. 72).

${ }^{63}$ Orz. z dnia 19.12.2017 r. [niepubl.]. Omawiam za A. Anthimos: No recognition...

${ }^{64} \mathrm{~W}$ rozstrzyganej przez sąd w Thessalonikach sprawie chodziło o rozwód talaq przeprowadzony pod rządami prawa egipskiego i potwierdzony świadectwem biura notarialnego w Egipcie. Grecki sąd odmówił uznania rozwodu talaq, wskazując na jego jednostronny charakter. Podkreślił, że rozwód taki jest całkowicie sprzeczny z podstawowymi zasadami zarówno greckiego, jak i europejskiego porządku prawnego. Przywołał w tym względzie postanowienia greckiej konstytucji, jak i EKPCz (art. 6, 8 i 14). Dwa aspekty rozstrzygnięcia wywołuja jednak wątpliwości. Po pierwsze, jedynym powiązaniem sprawy z terytorium Grecji było obecne miejsce pobytu żony (świeżo nabyte). W chwili przeprowadzania rozwodu małżonkowie zamieszkiwali bowiem na stałe w Egipcie. Po drugie, inaczej niż dzieje się to zazwyczaj, o uznanie rozwodu wystąpiła żona. Trudno zatem kwestionować, że wyraziła ona w ten sposób zgodę na rozwód i akceptację przeprowadzonej procedury talaq. Odmowa uznania dokonanego w Egipcie rozwodu oznaczała zaś, że żona zmuszona była wystapić o rozwód (ponowny) w Grecji. Konieczność ta rodzi określone trudności po stronie kobiety. Przede wszystkim nie ma pewności, że greckie sądy miałyby jurysdykcję krajową do oceny powództwa rozwodowego. Ponadto, pozew 


\section{Postanowienie Sądu Apelacyjnego w Katowicach $\mathrm{z}$ dnia 20 sierpnia $2009 \mathrm{r}$.}

Wedle wiedzy autora, jedynym publikowanym rozstrzygnięciem sądu polskiego dotyczącym problemu uznania w Polsce jednostronnego rozwodu przeprowadzonego pod rządami prawa muzułmańskiego jest postanowienie Sądu Apelacyjnego w Katowicach z 20 sierpnia 2009 r. Chociaż jest to orzeczenie sprzed ponad 10 lat, zasługuje na bliższą uwagę doktryny prawa prywatnego międzynarodowego i szczegółowe uwagi w tym miejscu.

Emir M., obywatel Maroka i Polski, wniósł o uznanie w Polsce świadectwa rozwodu wystawionego przez notariusza Biura Notarialnego Spraw Osobowych w Egipcie, stwierdzającego rozwiązanie przez rozwód jego małżeństwa z Peggy P., obywatelką francuską, a od 2007 r. również obywatelką RP. Choć z uzasadnienia postanowienia nie wynika jasno, gdzie strony zawarły związek małżeński, wydaje się, że nastąpiło to za granica w 1992 r. Małżeństwo to zostało zarejestrowane w polskim rejestrze stanu cywilnego w 2007 r. Jeszcze wcześniej, bo w 2001 r., Emir M. złożył jednak przy świadkach oświadczenie o rozwodzie, zgodnie z tradycyjną formuła znaną prawu muzułmańskiemu. W styczniu $2007 \mathrm{r}$. Emir M. uzyskał świadectwo rozwodu wystawione przez notariusza w Biurze Notarialnym Spraw Osobowych w Egipcie, po czym wniósł o jego uznanie w Polsce. W kwietniu 2007 r. Peggy P. odpowiedziała, kierując do sądu polskiego pozew o rozwód przeciwko Emirowi M.

Na skutek anonimizacji danych stron dość niejasne stało się uzasadnienie postanowienia $\mathrm{w}$ przedmiocie miejsca zamieszkania stron, co jest o tyle niekorzystne, że okoliczność ta ma - w mojej ocenie — istotne znaczenie w kontekście przesłanek stosowania klauzuli porządku publicznego. Sąd informuje, że Emir M. mieszkał w Polsce począwszy od $1961 \mathrm{r}$. Natomiast jako miejsce zamieszkania Peggy P. w egipskim świadectwie rozwodu podano hotel S. w H., co Sąd przytacza bez komentarza. Można się domyślać, że chodzi tu o miejsce znajdujące się za granica. W innym bowiem fragmencie uzasadniania Sąd stwierdza, że ostatnie wspólne miejsce zamieszkania znajdowało się w K., a z kontekstu można wnosić, że K. to miejscowość w Polsce. Nie ma tu jednak pewności. Nie wiemy

musiałby być doręczony mężowi w Egipcie. Grecki sąd mógłby być zmuszony zasięgać informacji o prawie egipskim. Wreszcie, kobieta musiałaby ponosić koszty prawdopodobnie długotrwałego i złożonego postępowania. Z tych powodów orzeczenie sądu w Thessalonikach spotkało się z przekonująca - w mojej ocenie - krytyka. Zob. A. Anthimos: No recognition... 
ponadto, gdzie znajdowało się miejsce zamieszkania żony w chwili składania przez Emira M. oświadczenia o rozwodzie, tj. w 2000 r.

Oddalając wniosek Emira M. o uznanie egipskiego świadectwa rozwodowego, Sąd Apelacyjny w Katowicach, po pierwsze, rozważył, czy w sprawie nie znajduje zastosowania Konwencja haska o uznawaniu rozwodów i separacji z dnia 1 czerwca 1970 r. ${ }^{65}$, której stroną jest Rzeczpospolita. Sąd ustalił, że nie znajduje ona zastosowania we wzajemnych stosunkach pomiędzy Polską a Egiptem. Następnie Sąd wyjaśnił, że w sprawie nie znajduje zastosowania także umowa między RP a Egiptem $\mathrm{z}$ dnia 17 maja 1992 r. o pomocy prawnej w sprawach cywilnych i handlowych ${ }^{66}$ (ponieważ nie obejmuje ona spraw rodzinnych).

W dalszej kolejności SA przywołał art. 18 ustawy - Prawo prywatne międzynarodowe z 1965 r. [dalej: p.p.m. 1965] ${ }^{67}$. Zgodnie z tym przepisem, w braku wspólnego prawa ojczystego małżonków dla rozwodu stosować należało prawo państwa, w którym oboje małżonkowie zamieszkuja. Ponadto, zgodnie z art. 2 p.p.m. 1965, obywatel polski podlegał prawu polskiemu, chociażby prawo innego państwa uznawało go za obywatela tego państwa. Doprowadziło to SA do niewypowiedzianej konkluzji, że właściwe dla rozwodu byłoby prawo polskie. Wydaje się o tym świadczyć także stwierdzenie Sądu, że „zbędnym w sprawie było ustalanie treści prawa i procedury egipskiej w zakresie rozwiązywania małżeństwa opartego na prawie muzułmańskim".

Inaczej niż sąd pierwszej instancji, Sąd Apelacyjny przyjął, że świadectwo rozwodowe wystawione przez biuro notarialne spraw osobowych w Egipcie stanowi rozstrzygnięcie obcego organu, które może podlegać uznaniu na podstawie art. 1145 i n. k.p.c. SA podkreśla, że przepisy tytułu I Księgi Trzeciej k.p.c. dotyczą nie tylko orzeczeń obcych sądów, lecz także rozstrzygnięć innych organów. Podpiera się w tym względzie nowelizacja przepisów z 2009 r., która wprowadziła do Kodeksu postępowania cywilnego przepis art. $1149^{1}$ k.p.c. W sprawie nie chodziło zatem o stosowanie prawa właściwego dla rozwodu, lecz o uznanie rozstrzygnięcia egipskiego organu - biura notarialnego spraw osobowych.

Są Apelacyjny wskazał na trzy okoliczności, które jego zdaniem przemawiaja za odmowa uznania w Polsce świadectwa rozwodowego przedstawionego przez Emira M. Po pierwsze, według ustaleń SA, od rozstrzygnięcia biura notarialnego przysługiwało odwołanie. Wnioskodawca nie wykazał, że jego żonie dostarczono świadectwo, i że stało się ono ostateczne. Nie była zatem spełniona przesłanka prawomocności rozstrzygnięcia w państwie pochodzenia (art. $1146 § 1$ pkt 1 k.p.c.).

65 Dz.U. 2001, nr 53, poz. 561.

66 Dz.U. 1994, nr 34, poz. 126.

67 Ustawa z dnia 12 listopada 1965 r. Dz.U. nr 46, poz. 290 ze zm. 
Po drugie, naruszone zostało prawo do obrony Peggy P. Nie uczestniczyła ona bowiem w postępowaniu, które zakończyło się wydaniem świadectwa rozwodu. Emir M. nie przedstawił dowodu, że Peggy M. została prawidłowo wezwana do udziału w tym postępowaniu, a ona sama zaprzeczyła, aby doręczono jej wezwanie i świadectwo rozwodu. Na przeszkodzie uznaniu stały zatem art. $1146 \S 1$ pkt 3 k.p.c. oraz art. $1147 \S 2$ k.p.c.

Wreszcie trzecim - i najbardziej interesujacym pod względem prowadzonych tu rozważań - powodem, dla którego świadectwo rozwodu nie mogło być uznane, była sprzeczność skutków jego uznania z podstawowymi zasadami porządku prawnego RP (klauzula porządku publicznego; art. $1146 \S 1$ pkt 7 k.p.c.). SA podkreśla, że rozwiązanie małżeństwa na skutek jednostronnego oświadczenia męża, bez uwzględnienia stanowiska żony, sprzeciwia się zasadzie trwałości małżeństwa i równouprawnienia małżonków, które chronione są także na poziomie konstytucyjnym (art. 18 Konstytucji RP). To zaś, że oceniany rozwód był jednostronny, wynikało już z samej treści świadectwa rozwodowego.

\section{5. Świadectwo rozwodu wystawione przez biuro notarialne}

Jedną z trudności, która może się pojawić w kontekście rozwodów talaq, jest pytanie o rodzaj rozstrzygnięcia, które podlegać ma uznaniu, w kontekście organu władzy publicznej, od którego ono pochodzi. Obrazuje to dobrze omawiane tu orzeczenie Sądu Apelacyjnego w Katowicach. Zdaniem tego Sąu, świadectwo rozwodowe wystawione przez biuro notarialne spraw osobowych w Egipcie stanowi rozstrzygnięcie obcego organu, które może podlegać uznaniu na podstawie art. 1145 i n. k.p.c. Wniosek ten budzi jednak wątpliwości. Warto poczynić w tym względzie krótkie uwagi.

Oczywiste jest, że na tle przepisów Kodeksu postępowania cywilnego nie tylko orzeczenia sądów podlegają uznaniu. Stwierdzenie to było trafne na tle stanu prawnego sprzed 2009 r., a obecnie nie budzi już wątpliwości z uwagi na brzmienie art. $1149^{1}$ k.p.c. Przepis ten stanowi, że przepisy dotyczące uznawania orzeczeń stosuje się odpowiednio do rozstrzygnięć innych organów państw obcych wydanych w sprawach cywilnych. W doktrynie wskazuje się, że pod tym pojęciem „należy rozumieć akt władczy $\mathrm{w}$ granicach jego kompetencji, który wywołuje określony przez prawo skutek prawny" ${ }^{\prime 2}$. Artykuł $1149^{1}$ k.p.c. znajduje zastosowa-

${ }^{68}$ P. Borkowski, w: Kodeks postępowania cywilnego. Komentarz. Art. 506-1217. T. 2. Red. T. Szanciło. Warszawa 2019, kom. do art. $1149^{1}$, pkt 2. 
nie do takich aktów organów państw obcych, które wydawane są w sprawach cywilnych. Znaczenie „sprawy cywilnej” ustalać zaś należy w świetle kryteriów wskazanych w art. 1 k.p.c. ${ }^{69}$ Zdaniem np. Sądu Okręgowego $\mathrm{w}$ Warszawie ${ }^{70}$, jeśli sprawa jest np. sprawa z zakresu prawa rodzinnego, to już z tego powodu należy do kategorii spraw cywilnych w rozumieniu art. $1149^{1}$ k.p.c.

Rozstrzyganie spraw, które w Polsce powierzone są sądom, może $\mathrm{w}$ innych państwach być powierzone innego rodzaju organom. Dotyczy to w szczególności rozwodów przeprowadzanych w trybie administracyjnym (taki tryb jest współcześnie znany w wielu krajach i nie dotyczy wyłącznie rozwodów jednostronnych). Administracyjny charakter rozstrzygnięcia nie wyklucza możliwości jego uznania na zasadach analogicznych do uznawania orzeczeń. Rozwody administracyjne nie budzą już współcześnie takich zastrzeżeń jak dawniej. Dominuje stanowisko, że nie ma przeszkód, aby także takie rozwody były w Polsce uznawane ${ }^{71}$.

Należy jednak przeprowadzić rozgraniczenie pomiędzy zakresami zastosowania przepisów art. $1149^{1}$ k.p.c. i art. 1138 k.p.c. Ten ostatni dotyczy zagranicznych dokumentów urzędowych. Przepis ten zrównuje ich moc dowodowa $z$ polskimi dokumentami urzędowymi ${ }^{72}$. Nie dochodzi do uznania skutków materialnoprawnych określonych dokumentem, a jedynie do przypisania dokumentowi szczegółowej mocy dowodowej. W przeszłości wątpliwości co do właściwej kwalifikacji dotyczyły notarialnych

${ }^{69}$ T. Ereciński, J. Ciszewski, K. Weitz: Kodeks postępowania cywilnego. Komentarz. Warszawa 2009, s. 495, 553-554.

${ }^{70}$ Post. SO w Warszawie z dnia 14 lutego 2018 r., VI Co 1080/16.

${ }^{71} \mathrm{~W}$ przeszłości w orzecznictwie wyrażane było stanowisko niechętne uznawaniu rozwodów przeprowadzanych za granica w trybie administracyjnym. Wątpliwości co do zasadności takiego stanowiska wyrażał już w latach siedemdziesiątych ubiegłego wieku M. Tomaszewski: W sprawie skuteczności $w$ Polsce zagranicznych rozwodów administracyjnych. „Państwo i Prawo” 1979, z. 8-9, s. 118 i n. Obecnie zdecydowanie przeważa pogląd, że rozwody przeprowadzone w trybie administracyjnym mogą być - co do zasady - uznawane. Tak T. Strumiłło, w: Kodeks postepowania cywilnego. T. 2: Komentarz. Art. 730-1217. Red. J. Jankowski. Wyd. 2. Warszawa 2015, kom. do art. $1149^{1}$. Silnym wsparciem dla takiego poglądu jest art. $1149^{1}$ k.p.c., zgodnie z którym przepisy dotyczące uznawania zagranicznych orzeczeń stosuje się odpowiednio do rozstrzygnięć innych organów państw obcych wydanych w sprawach cywilnych. Nie jest też przeszkodą dla uznania rozwodu sama okoliczność, że o rozwodzie orzekał obcy sąd religijny, o ile sąd taki współtworzy państwowy system wymiaru sprawiedliwości. Zob. A. Torbus, w: Komentarz do kodeksu postępowania cywilnego. T. 4. Red. K. Piasecki, A. Marciniak. Warszawa 2017, art. 1098, nb. 10.

${ }^{72}$ Zob. np. Ł.D. Dąbrowski: Moc dowodowa zagranicznych dokumentów urzędowych. Wybrane zagadnienia procesowe. „Problemy Współczesnego Prawa Międzynarodowego, Europejskiego i Porównawczego" 2016, vol. 14, s. 120 i n.; M. Wojewoda: Moc dowodowa zagranicznych dokumentów urzędowych. W: „System Prawa Prywatnego”. T. 20C: Prawo prywatne międzynarodowe. Red. M. Pazdan. Warszawa 2015, s. 532. 
poświadczeń dziedziczenia. Obecnie jest już jednak jasne, że chodzi $\mathrm{w}$ takim wypadku o rozstrzygnięcia podlegające uznaniu na podstawie art. 1145 i n. k.p.c. w zw. z art. $1149^{1}$ k.p.c., a nie jedynie o dokumenty urzędowe $\mathrm{z}$ art. 1138 k.p.c. ${ }^{73}$

Kwestia, czy świadectwo rozwodowe biura notarialnego w Egipcie powinno być uznawane jako „rozstrzygnięcie innego organu” w rozumieniu art. $1149^{1}$ k.p.c. nie jest zatem, w mojej ocenie, oczywista. Chodzi tu oczywiście o sprawę cywilną w znaczeniu, w jakim pojęcie to funkcjonuje w polskim Kodeksie postępowania cywilnego. Jednak inicjowany przez męża rozwód talaq nie jest przeprowadzany przed biurem notarialnym. Urzędnik biura notarialnego nie „rozstrzyga” o rozwodzie. Zgodnie z prawem egipskim i przyjęta praktyka, rozwód dokonuje się za pomocą oświadczenia woli męża i jest następnie jedynie rejestrowany w terminie 30 dni $\mathrm{w}$ biurze notarialnym ${ }^{74}$. Taka rejestracja jest obowiazkowa ${ }^{75}$. Biuro notarialne ma także obowiazek zawiadomienia żony o jej odrzuceniu przez męża. Nie oznacza to jednak, że toczy się przed nim jakiś realny spór między stronami. Nie ma zatem pewności, że chodzi tu o „rozstrzygnięcie sprawy cywilnej”, które mogłoby podlegać uznaniu z mocy art. $1149^{1}$ k.p.c.

Warto też zwrócić uwagę, że w praktyce rozwody talaq często nie są $\mathrm{w}$ ogóle rejestrowane ${ }^{76}$. W tradycji państw muzułmańskich, w tym Egiptu, uczestnictwo organów państwowych w sprawach dotyczących prawa rodzinnego jest bowiem czymś nowym i jeszcze się nie upowszechniło. Pozostawia to otwarte pytanie o konsekwencje niezarejestrowanego rozwodu talaq, w szczególności zaś czy brak rejestracji oznacza, że rozwód nie wywołuje skutku w postaci rozwiązania małżeństwa.

${ }^{73}$ Zob. post. SO w Kielcach z dnia 5 lutego 2015 r., II CA 1533/14, II CZ 1784/14, które spotkało się z przychylnym przyjęciem w doktrynie. Zob. M. Margoński: Skutki $w$ Polsce poświadczenia dziedziczenia dokonanego przez notariusza holenderskiego. Glosa do postanowienia Sadu Okregowego w Kielcach z dnia 5 lutego 2015 r. (II CA 1533/14, II CZ 1784/14). „Nowy Przegląd Notarialny” 2015, nr 3, 64 (który wskazuje, że notarialne poświadczenie dziedziczenia stanowi „podręcznikowy przykład” rozstrzygnięcia organu pozasądowego w rozumieniu art. $1149^{1}$ k.p.c.). Jednakże w wyr. WSA w Warszawie z dnia 1 lipca 2014 r., I SA/Wa 300/14, przyjęto, że zagraniczne poświadczenie dziedziczenia stanowi jedynie dokument urzędowy, któremu przysługuje moc dowodowa z art. 1138 k.p.c., a nie rozstrzygnięcie obcego organu, o którym mowa w art. $1149^{1}$ k.p.c.

${ }^{74}$ N. Salem: The Impact of the Convention on the Elimination of All Forms of Discrimination against Women on the Domestic Legislation in Egypt. Leiden-Boston 2018, s. 88; F. Deif: Divorced from Justice: Women's Unequal Access to Divorce in Egypt. „Human Rights Watch" 2004, vol. 16, no. 8, s. 19; I. Sportel: Divorce in Transnational Families: Marriage, Migration and Family Law. Palgrave Mcmillian 2016, s. 63; M. Lindbekk: Inscribing Islamic Shari’a in Egyptian Divorce Law. „Oslo Law Review” 2016, vol. 3 , no. 2 , za przyp. 50 .

${ }^{75}$ I. Sportel: Divorce..., s. 63.

${ }^{76}$ M. Lindbekk: Inscribing..., za przyp. 53. 
Jak wspomniano wyżej, Sąd Apelacyjny w Katowicach uznał za zbędne ustalanie treści prawa i procedury egipskiej dotyczących rozwodu. Nie ustalił zatem, jaki był charakter rejestracji rozwodu przez biuro notarialne w prawie egipskim. Sąd stwierdza jedynie, że było bezsporne, iż świadectwo rozwodu ma charakter deklaratoryjny, i że żona ma prawo się od niego odwołać. Trudno w konsekwencji ocenić, czy rzeczywiście świadectwo rozwodu wydane przez biuro notarialne powinno być uznane za rozstrzygnięcie obcego organu podlegajace uznaniu na podstawie art. $1149^{1}$ k.p.c. Wydaje się, że Sąd Apelacyjny powinien był przeprowadzić dowód na okoliczność treści prawa egipskiego, co pozwoliłoby w sposób precyzyjny określić charakter świadectwa rozwodu. W tym celu Sąd mógł skorzystać z dostępnych środków dowodzenia treści prawa obcego: informacji Ministerstwa Sprawiedliwości lub opinii biegłego ${ }^{77}$.

\section{Znaczenie polskiego aktu stanu cywilnego a prawo właściwe dla małżeństwa}

W omawianym tu postanowieniu Sąd Apelacyjny w Katowicach stwierdza, że skoro związek małżeński został zarejestrowany w polskim urzędzie stanu cywilnego i w konsekwencji został sporządzony polski akt małżeństwa, to dopóki ten akt nie zostanie unieważniony „strony na obszarze Rzeczypospolitej Polskiej traktowane sa jako małżeństwo w rozumieniu polskiego prawa rodzinnego". Stwierdzenie to wymaga komentarza. Nie może być ono zbyt szeroko rozumiane. W żadnym razie nie można twierdzić, że małżeństwo zarejestrowane w polskim USC podlega $\mathrm{z}$ tego powodu polskiemu prawu. O tym, jakiemu prawu podlega małżeństwo (a ściślej — poszczególne przesłanki i skutki małżeństwa), rozstrzygają bowiem normy kolizyjne prawa prywatnego międzynarodowego. I tak, np. o zawarciu małżeństwa rozstrzyga w stosunku do każdej ze stron jej prawo ojczyste z chwili jego zawarcia (art. 48 p.p.m..$^{78}$ ), natomiast stosunki osobiste i majątkowe między małżonkami podlegaja każdoczesnemu wspólnemu prawu ojczystemu (art. 51 p.p.m.).

Rejestracja małżeństwa $\mathrm{w}$ polskim USC niczego nie zmienia na płaszczyźnie prawa materialnego. Prowadzi ona jedynie do powstania

${ }^{77}$ Dawniej art. 1143 k.p.c.; obecnie art. 51a $\$ 3$ ustawy z dnia 27 lipca 2001 r. — Prawo o ustroju sądów powszechnych. T.j. Dz.U. 2020, poz. 365.

${ }^{78}$ Ustawa z dnia 4 lutego 2011 r. - Prawo prywatne międzynarodowe. Dz.U. nr 80, poz. 432 . 
polskiego aktu stanu cywilnego, któremu przysługuje szczególna moc dowodowa na podstawie art. $3 \operatorname{PrASC}^{79}$. Dopóki funkcjonuje on w obrocie, dopóty stanowi wyłączny dowód małżeństwa. Nie przesądza jednak - w znaczeniu materialnym - ani o istnieniu małżeństwa, ani o innych kwestiach małżeństwa dotyczących. Jeżeli akt nie odpowiada rzeczywistemu stanowi rzeczy, może zostać usunięty z obrotu. Jeśli zatem małżeństwo zarejestrowane w Polsce zostało za granica rozwiązane, to można dochodzić unieważnienia polskiego aktu stwierdzającego to małżeństwo. Moga tu wystąpić dwa rodzaje przypadków. Po pierwsze, jeśli małżeństwo rozwiązane zostało wyrokiem sądu lub rozstrzygnięciem innego organu, to podlegaja one, co do zasady, uznaniu z mocy prawa (art. 1145 k.p.c. w stosunku do orzeczeń i art. $1149^{1}$ k.p.c. w stosunku do rozstrzygnięć innych organów). Zainteresowana strona może też wystąpić do sądu z wnioskiem o ustalenie, że orzeczenie sądu państwa obcego lub rozstrzygnięcie innego organu rozwiązujące małżeństwo (bądź stwierdzające jego rozwiązanie) podlega uznaniu (art. 1148 k.p.c.).

Po drugie, w przypadku gdy chodzi o rozwody prywatne (dokonywane czynnością prawna), wydaje się, że właściwym trybem postępowania byłoby wytoczenie w Polsce powództwa o ustalenie w trybie art. 189 k.p.c., że małżeństwo ustało. Wnioskodawca dochodziłby w takim wypadku stwierdzenia, że na skutek prywatnego rozwodu przeprowadzonego za granica małżeństwo ustało. Taka sytuacja jest do wyobrażenia jedynie w przypadku, w którym prawem właściwym dla rozwodu, zgodnie z art. 54 p.p.m., jest prawo obce, przewidujące możliwość rozwiazzania małżeństwa bez udziału sądu czy innego organu władzy publicznej ${ }^{80}$. Pojawia się jednak pytanie, czy prywatne rozwody w ogóle moga być akceptowane. Sprzeciwiaja się one przyjętej w Polsce zasadzie, że o rozwiązaniu małżeństwa orzeka sąd. Rozważać można interwencję klauzuli porządku publicznego ${ }^{81}$. Jeżeli jednak rozwód przeprowadzony został z zachowaniem równości małżonków i ich praw przy rozwiązaniu małżeństwa oraz $\mathrm{w}$ poszanowaniu dla trwałości małżeństwa, to interwencja klauzuli może nie być konieczna.

Inna jest kwestia, że w praktyce skuteczniejszym środkiem zmierzającym do zakończenia związku małżeńskiego w Polsce może się okazać pozew rozwodowy w Polsce (nawet jeśli oznacza to de facto ponowny rozwód).

${ }^{79}$ Poprzednio art. 4 ustawy z dnia 29 września 1986 r. - Prawo o aktach stanu cywilnego. Dz.U. 2011, nr 212, poz. 1264 ze zm.

80 Por. A. Kozioł, w: Komentarz..., Red. M. Pazdan [2018], s. 498.

${ }^{81}$ I tak np. w Szwajcarii przyjmuje się, że nie może być zaakceptowany rozwód, jeżeli brak było oceny sądu w przedmiocie rozkładu pożycia małżeńskiego, a żona opiera się rozwiązaniu małżeństwa. Tak A. Büchler, A. Latif: Judicial..., s. 73. 
Uznanie w Polsce rozstrzygnięcia obcego organu stwierdzajacego rozwiązanie małżeństwa (z samej mocy prawa) oznacza, że właściwe zmiany powinny zostać uwidocznione $\mathrm{w}$ polskim rejestrze stanu cywilnego, w którym istnieje akt małżeństwa rozwiązanego za granica. Z kolei jeśli chodzi o rozwody prywatne (dokonywane czynnością prawna), zmiana $\mathrm{w}$ rejestrze stanu cywilnego możliwa będzie po uprzednim ustaleniu przez polski sąd w trybie art. 189 k.p.c. faktu rozwiązania małżeństwa takim rozwodem.

\section{Klauzula porządku publicznego a uznawanie rozwodów talaq w Polsce}

Nie budzi wątpliwości, że rozwiązanie małżeństwa na skutek jednostronnego oświadczenia męża, bez uwzględnienia stanowiska drugiego z małżonków, sprzeciwia się zasadzie równouprawnienia małżonków, podstawowej dla naszego porządku prawnego. Rozwód talaq jako sposób rozwiązania małżeństwa dostępny wyłącznie dla mężczyzny razi swym dyskryminacyjnym charakterem. Równouprawnienie kobiety i mężczyzny w małżeństwie należy do zasad najbardziej podstawowych. Podkreślaja to zarówno przepisy krajowe (art. 23 k.r.o., art. 18 w zw. z art. 32 Konstytucji RP), unijne (zwłaszcza art. 20, 21 i 23 Karty Praw Podstawowych), jak i prawa międzynarodowego ${ }^{82}$, w szczególności EKPCz (art. 14). Na fundamentalny charakter tej zasady wskazuje także orzecznictwo ${ }^{83}$ i doktryna ${ }^{84}$. Już z tego tylko powodu rozwody przez odrzucenie nie powinny być co do zasady uznawane w naszym kraju.

Z kolei łatwość przeprowadzenia rozwodu talaq (rozwiązanie małżeństwa na skutek samego oświadczenia męża) godzi w zasadę trwałości

${ }^{82}$ Zob. np. Konwencja Narodów Zjednoczonych z dnia 18 grudnia 1979 r. w sprawie likwidacji wszelkich form dyskryminacji kobiet. Dz.U. 1982, nr 10, poz. 70.

${ }^{83}$ Zob. np. orz. SW w Zielonej Górze z dnia 21 lutego 1975 r., II Cr 109/75. OSP 1976, poz. $9 \mathrm{z}$ aprobująca glosa J. Jodłowskiego; orz. SN z dnia 20 stycznia 1983 r., III CZP 37/82. OSNCP 1983, nr 8, poz. 107; post. SA w Warszawie z dnia 3.10 .1997 r., I Acz $472 / 97$.

${ }^{84}$ Zob. np. M. Sośniak: Zasada równorzędności ptci w zakresie zawarcia, unieważnienia $i$ rozwiazania matżeństwa $w$ socjalistycznych systemach prawa międzynarodowego prywatnego ze szczególnym uwzględnieniem prawa polskiego. „Studia Prawnicze” 1978, nr 3, s. 22 i n.; A. Sapota: Wybór prawa $w$ międzynarodowym prawie rodzinnym. Warszawa 2016, s. 259; A. Koziol, w: Komentarz..., Red. M. Pazdan [2018], s. 496; M. Zachariasiewicz, w: Komentarz..., Red. M. Pazdan [2018], s. 146. 
małżeństwa, którą również uważa się za jedną z podstawowych zasad polskiego prawa rodzinnego ${ }^{85}$, zakorzeniona (choć nie expressis verbis) także w Konstytucji ${ }^{86}$. Podkreśla się, że w razie potrzeby zasada trwałości małżeństwa chroniona jest także za pomoca klauzuli porządku publicznego ${ }^{87}$. Warto jednak zauważyć, że małżeństwo w prawie polskim ma charakter trwały, ale rozwiązalny. Zakłada to określona równowagę pomiędzy tymi cechami. Odmienna ocena prawa obcego co do trwałości i rozwiązalności małżeństwa nie może być co do zasady podstawa do ingerencji klauzuli porządku publicznego. Jednak w szczególnych przypadkach wykraczających poza akceptowalny obszar tej równowagi ingerencja klauzuli może być uzasadniona ${ }^{88}$. Wydaje się, że przypadek, w którym mąż może rozwiązać małżeństwo za pomoca zwykłego oświadczenia, bez konieczności spełniania jakichkolwiek przesłanek, godzi w zasadę trwałości małżeństwa i uzasadnia zastosowanie klauzuli. Nie wszystkie przypadki rozwodów na tle prawa muzułmańskiego (nawet określane mianem talaq) są jednak identyczne. Jak już powiedziano, niekiedy oświadczenie męża inicjuje jakiegoś rodzaju postępowanie (nawet jeśli nie sądowe), w którym - pomimo braku pełnej równości stron - następuje jednak weryfikacja jakichś przesłanek, próba koncyliacyjna pomiędzy małżonkami itp. Niektóre spośród tych przypadków moga być akceptowane (o ile nierówność między małżonkami w odniesieniu do rozwiązania małżeństwa jest kompensowana innymi okolicznościami, w szczególności zgodą kobiety na rozwód lub zabezpieczeniem jej interesów majątkowych). W każdym zatem przypadku należy badać całokształt okoliczności faktycznych i prawnych rozwodu przeprowadzonego na podstawie prawa muzułmańskiego.

Najmniej rażąca wydaje się natomiast z naszej perspektywy okoliczność, że rozwód talaq ma z reguły (choć nie zawsze) charakter prywatny, tzn. nie wymaga udziału jakiegokolwiek organu dla swej skuteczności

85 T. Smyczyński: Prawo rodzinne i opiekuńcze. Wyd. 9. Warszawa 2018, s. 167.

${ }^{86}$ M. Eaczkowska: Zasada trwałości matżeństwa $w$ polskim prawie rodzinnym aspekty materialne i procesowe. „Studia Prawnoustrojowe” 2014, nr 24, s. 61 i n.; J. Podkowik: Prawo rzeczowe, spadkowe i rodzinne $w$ orzecznictwie Trybunatu Konstytucyjnego. „Kwartalnik Prawa Prywatnego” 2017, z. 4, s. 793.

${ }^{87} \mathrm{~W}$ orzecznictwie tak np. post. SA w Warszawie z dnia 3 października $1997 \mathrm{r}$., I ACz 472/97. Legalis. W doktrynie tak M. Mączyński: Kodyfikacyjne zagadnienia części ogólnej prawa prywatnego międzynarodowego. W: Studia i rozprawy. Księga jubileuszowa dedykowana profesorowi Andrzejowi Całusowi. Red. A. Janik. Warszawa 2009, s. 233.

${ }^{88} \mathrm{~W}$ doktrynie wspomina się o przykładzie orzekania o rozwodzie bez konieczności spełnienia jakichkolwiek przesłanek. Zob. M. Pazdan: Prawo prywatne międzynarodowe. Warszawa 2017, s. 306; A. Kozioł, w: „System Prawa Prywatnego”. T. 20C... Red. M. Pazdan, s. 265; A. Sapota: Wybór prawa..., s. 259, 261. 
(tzw. bare talaq). Wprawdzie taki charakter rozwodu jest zdecydowanie obcy naszej tradycji prawnej, ale sam w sobie nie wydaje się godzić $\mathrm{w}$ podstawowe zasady porządku publicznego. To, co oburza nas $\mathrm{w}$ rozwodach talaq, to przede wszystkim ich dyskryminacyjny i jednostronny charakter, a w drugiej kolejności także łatwość, z jaką mąż może rozwiazać swe małżeństwo, a nie sam fakt, że odbywa się to bez jakiegokolwiek udziału organu władzy publicznej. Teoretycznie, gdyby rozwód następował $\mathrm{w}$ formie rozwiąania przez małżonków umowy małżeńskiej z zachowaniem równości praw obydwu stron i przy poszanowaniu trwałości, to nie istniałaby konieczność jego zanegowania. Należy jednak pamiętać, że w ramach rozwodów talaq ich prywatny charakter staje się w istocie nośnikiem łatwości jednostronnego rozwiązania małżeństwa przez męża z pokrzywdzeniem kobiety.

Łagodniej ocenia się $\mathrm{w}$ państwach zachodnioeuropejskiej kultury prawnej rozwody, w ramach których ma miejsce jakaś postać postępowania przed organem władzy publicznej (tzw. formal talaq). W szczególności chodziło w orzecznictwie o przypadki, w których przeprowadzono procedurę koncyliacyjna przed specjalną radą arbitrażową (zob. wyżej pkt 3). Może też chodzić o sytuację, jaka zaistniała w stanie faktycznym ocenianym przez Są Apelacyjny w Katowicach we wspominanym tu często postanowieniu, tj. o przypadek, w którym stwierdzenia rozwodu dokonuje biuro notarialne. Taka procedura może - choć nie musi - gwarantować zachowanie prawa kobiety do kwestionowania rozwodu, jako nieuzasadnionego w świetle prawa dla niego właściwego. Należy jednak pamiętać, że w ramach rozwodów przeprowadzanych przy określonym udziale organu władzy publicznej (formal talaq) pojawić może się problem ewentualnego naruszenia prawa do obrony żony. Takie ustalenia poczynił Sąd Apelacyjny w Katowicach w ocenianym stanie faktycznym. Ustalił on mianowicie, że żona nie została prawidłowo wezwana do udziału w postępowaniu przed biurem notarialnym i w nim nie uczestniczyła. Co więcej, nie doręczono jej świadectwa rozwodu. Okoliczności te uzasadniły, zdaniem Sądu Apelacyjnego, przyjęcie, że świadectwo to nie może podlegać uznaniu w Polsce ${ }^{89}$.

Pomimo zasadniczego sprzeciwu polskiego porządku prawnego przeciwko rozwodom talaq, indywidualne okoliczności sprawy mogą niekiedy

${ }^{89}$ Nie jest jednak pewne, czy zachowanie prawa do obrony żony w postępowaniu przed biurem notarialnym zmieniałoby cokolwiek w ocenie dopuszczalności uznania świadectwa rozwodu. W postępowaniu tego typu, w typowym przypadku, dochodzi jedynie do stwierdzenia rozwodu już dokonanego wcześniej. Nie toczy się w nim rzeczywisty spór między stronami. Nie wydaje się, aby odrzucana żona miała tu jakiekolwiek realne możliwości opierania się rozwodowi. Jej udział w postępowaniu przed notariuszem nie uchyla zatem jednostronności i dyskryminacyjnego charakteru rozwodu talaq. 
przemawiać za potrzebą uznania rozwodu talaq lub przynajmniej niektórych jego skutków. Sądy polskie stykające się z taką postacią rozwiązania małżeństwa powinny prowadzić wnikliwą ocenę całokształtu okoliczności sprawy i ocenić zasadność odmowy jego uznania w świetle kryteriów, które zrekonstruować można na podstawie omawianego wyżej (pkt 3) orzecznictwa sądów państw Europy Zachodniej i Ameryki Północnej, które częściej stykały się z rozwodami talaq. Kryteria te nie stanowią oczywiście zero-jedynkowych probierzy, których obecność w każdym przypadku uruchamia powinność uznania rozwodu przez odrzucenie. Sa to raczej okoliczności, których występowanie może sugerować zasadność odmowy ingerencji klauzuli porządku publicznego $\mathrm{w}$ omawianym obszarze. W mojej ocenie, za relewantne należy uznać następujące kryteria.

Po pierwsze, istotne znacznie ma tu siła powiązań sprawy z terytorium państwa sądu orzekającego (forum). Przyjmuje się (choć niejednolicie) także w Polsce ${ }^{90}$, że związek sprawy z forum stanowi jedną z przesłanek stosowania klauzuli porządku publicznego. Im silniejsze powiązanie sprawy $\mathrm{z}$ forum, tym bardziej uzasadniona ingerencja $\mathrm{w}$ ochronie własnych zasad podstawowych. I odwrotnie - im słabsze związki faktyczne sprawy z obszarem prawnym forum, tym ostrożniejsze powinno być stosowanie klauzuli ${ }^{91}$. Jak wskazano wyżej, również w orzecznictwie dotyczącym rozwodów talaq stopień powiązania sprawy z forum (zwłaszcza miejsce zamieszkania małżonków) miał istotne znaczenie dla możliwości jego uznania w państwie europejskim. Jeżeli rozwód został przeprowadzony pomiędzy małżonkami zamieszkującymi w chwili rozwodu w państwie muzułmańskim i brak jest innych związków z europejskim obszarem prawnym, to okoliczność ta może przemawiać za uznaniem rozwodu talaq. Koncepcja związku z forum pozwala tu osiagnać równowage pomiędzy harmonią rozstrzygnięć w stosunkach międzynarodowych (przez poszanowanie odmiennych rozwiązań prawnych przyjętych w odmiennych kulturach prawnych i zdarzeń zaistniałych na obcym terytorium, gdy sprawa nie jest powiązana $\mathrm{z}$ forum) a ochroną własnych wartości (gdy związki z forum są silne).

${ }_{90}$ Post. SN z dnia 11 października 2013 r., I CSK 697/12. OSP 2014, nr 9, poz. 87. W doktrynie: K. Przybyłowski: Prawo prywatne międzynarodowe. Część ogólna. Lwów 1935, s. 167; M. Sośniak: Klauzula porzadku publicznego $w$ prawie międzynarodowym prywatnym. Warszawa 1961, s. 57-58; K. Pietrzykowski: Zawarcie małzeństwa $i$ przesłanki jego ważności $w$ prawie międzynarodowym prywatnym. Warszawa 1985, s. 46; M. Pilich: Zasada obywatelstwa $w$ prawie prywatnym międzynarodowym. Warszawa 2015, s. 492-493; M. Zachariasiewicz: Klauzula..., s. 205; Idem, w: Komentarz..., Red. M. Pazdan [2018], s. 147.

${ }^{91}$ Zob. szerzej M. Zachariasiewicz: Klauzula..., s. 200 i n. 
Po drugie, w ramach powiązań stanu faktycznego sprawy o charakterze przestrzennym znaczenie ma również oddalenie samych czynności składajacych się na rozwód. Jeśli rozwód - jako przyczyna ustania stosunku małżeństwa - nastąpił na terenie obcego państwa, w określonej przeszłości, to stanowi to argument, który może niekiedy przemawiać za uznaniem rozwodu talaq. Sądy powinny jednak przeciwdziałać turystyce rozwodowej, tj. przypadkom, w których mężczyzna mający miejsce zwykłego pobytu w Polsce wyjeżdża na krótko do kraju swego pochodzenia i tam dokonuje rozwodu lub rejestruje rozwód, domagając się następnie jego uznania w Polsce (fr. voyage de repudiation).

W kontekście znaczenia powiązań terytorialnych można zauważyć, że niedoskonałością uzasadnienia wspominanego tu wielokrotnie postanowienia Sadu Apelacyjnego w Katowicach jest niedostatek informacji na temat takich powiązań w ocenianym stanie faktycznym. Trudno na podstawie uzasadnienia postanowienia zorientować się dokładnie, $\mathrm{w}$ jakim stopniu oceniana sprawa była powiązania z terytorium RP. Choć wydaje się, że małżonkowie byli dość mocno związani z Polską i przynajmniej przez pewien okres mieli tu wspólne miejsce swego zamieszkania, to uzasadnienie nie daje tu pewności. Nie wiemy, czy coś się w tym zakresie zmieniło pomiędzy chwila rozwiązania małżeństwa w Egipcie a chwilą orzekania. Trudno w konsekwencji ocenić, na ile trafne były wywody Sądu w przedmiocie stosowania klauzuli porządku publicznego. Skoro istnieje niepewność co do związków małżonków z egipskim obszarem prawnym w chwili rozwodu, to nie da się ponadto ustalić, czy rozwód stwierdzony przez egipskie biuro notarialne nie był czasem przypadkiem turystyki rozwodowej (fr. voyage de repudiation).

Trzecią okolicznością, która może uzasadniać uznanie rozwodu talaq, jest potrzeba uwzględniania dalszych skutków życiowych, które nastapiły pomiędzy odrzuceniem żony a chwila, w której o kwestii uznania takiego rozwodu rozstrzyga polski sąd. Prawdopodobieństwu wystąpienia takich skutków (np. zawarcia kolejnego małżeństwa) sprzyja duże oddalenie w czasie rozwodu talaq (gdy nastąił wiele lat wcześniej na terytorium państwa, w którym w owym czasie zamieszkiwali małżonkowie). Uznanie rozwodu talaq powoduje w takim przypadku, że drugie małżeństwo jednej ze stron pierwszego jest skuteczne (bo nie naruszono zakazu bigamii) i nie można wnosić o stwierdzenie jego nieważności.

Czwartym powodem wzmacniającym racje przemawiające za uznaniem rozwodu talaq (ale $\mathrm{z}$ pewnością nie samoistnie uzasadniającym uznanie) jest okoliczność, że w toku rozwodu zapewniono kobiecie wystarczające gwarancje pod względem możności obrony jej praw. Nie zawsze bowiem rozwód talaq odbywa się pozasądownie i całkowicie jednostronnie. Niektóre jego formy stwarzają kobiecie określone możliwości 
opierania się rozwodowi, w tym poprzez konieczny udział organu władzy publicznej.

Po piąte, ostrze klauzuli porządku publicznego interweniujaccej przeciwko rozwodom talaq łagodzi zabezpieczenie interesów majątkowych odrzucanej żony - jeśli takowe nastapiło. Może to mieć miejsce na skutek zachowania przez żonę podarku małżeńskiego (mahr) o dużej wartości, tudzież inną formę (np. alimentacyjna) ${ }^{92}$. W przypadkach, w których zabezpieczenie majątkowe zależy od skuteczności rozwodu, odmowa jego uznania pozbawiałaby kobietę tegoż zabezpieczenia, czasem pozostawiając ją zupełnie bez środków do życia.

Wreszcie szóstą okolicznością, która może uzasadniać zaakceptowanie rozwodu talaq jest zgoda kobiety. Zgoda ta może zostać wyrażona w trakcie rozwodu, w szczególności jeśli odbyło się jakieś postępowanie rozwodowe, ale także na późniejszym etapie. Jeżeli jednak mąż powołuje się na zgodę żony wyrażona w toku rozwodu, to sąd musi dokładnie zbadać, czy rzeczywiście doszło do prawidłowo wyrażonej przez nią woli zakończenia małżeństwa. Ponadto, z reguły można przyjąć zgodę kobiety na rozwód, jeśli to ona występuje przed polskim sądem z wnioskiem o uznanie rozwodu talaq.

\section{Podsumowanie}

Rozwody talaq (rozwody przez odrzucenie), znane muzułmańskim systemom prawnym, sa bez watpienia niezgodne z podstawowymi zasadami polskiego porządku prawnego, w szczególności z zasada równouprawnienia małżonków i zasadą trwałości małżeństwa. Uznanie tego typu rozwodów może rodzić skutki sprzeczne z fundamentalnymi wartościami chronionymi w naszej kulturze prawnej. Pomimo to odmowa ich uznania nie będzie uzasadniona w każdym przypadku. Sąd rozstrzygający $\mathrm{w}$ tym przedmiocie zawsze powinien rozważyć całokształt okoliczności danego stanu faktycznego oraz konkretne skutki uznania lub nieuznania rozwodu talaq. Szczególne znaczenie mają powiązania terytorialne stanu faktycznego z polskim systemem prawnym (zwłaszcza miejsce zamieszkania/zwykłego pobytu małżonków), a także stopień

${ }^{92} \mathrm{~W}$ omawianym tu postanowieniu Sądu Apelacyjnego w Katowicach brak jest informacji, że Peggy P. otrzymała jakieś zabezpieczenie finansowe na skutek rozwodu. Można więc domniemywać, że go nie otrzymała. Gdyby jednak miało być inaczej, to stanowiłoby to argument za uznaniem rozwodu. 
oddalenia samego rozwodu (zarówno w przestrzeni, jak i czasie). Istotna rolę odgrywają także konkretne skutki danego rozwodu (finansowe, dalsze losy małżonków - zwłaszcza nowe związki małżeńskie). W każdym przypadku zetknięcia z rozwodem przez odrzucenie należy też brać pod uwagę sposób, w jaki rozwód ten został przeprowadzony, i jaka była rola organu władzy publicznej. Nigdy dość powtarzać, że rolą sądu jest wymierzanie - w ramach obowiązujacego porządku prawnego - sprawiedliwości w konkretnej sprawie, a nie bycie ślepym szafarzem pryncypiów, choćby uznawanych za podstawowe w naszym porządku prawnym.

\section{Bibliografia}

Anthimos A.: No recognition of an Egyptian talaq on public policy grounds. „International Civil Litigation in Greece”, 3.08.2018, icl-in-greece.blogspot. com.

Anthimos A.: Talaq v Greek public policy: Operation successful, patient dead..., 3.08.2018, conflictoflaws.net.

Bantekas I.: Transnational Talaq (Divorce) In English Courts: Law Meets Culture. „Journal of Islamic State Practice in International Law” 2013, no. 2.

Borkowski P., w: Kodeks postępowania cywilnego. Komentarz. Art. 506-1217. T. 2. Red. T. Szanciło. Warszawa 2019, kom. do art. 11491, pkt 2.

Büchler A., Latif A.: Judicial encounters with Islamic and Middle Eastern family law in Switzerland from a private international law perspective - marriage and divorce. In: Muslim Family Law in Western Courts. Ed. E. Giunchi. Abingdon 2014.

Carlier J.-Y.: Quand l’ordre public fair désordre. „Tijdschrift voor Belgisch Burgerlijk Recht” 2008, no. 9.

Carlier J.-Y., Henricot C.: Belgique, de l'exception d'ordre public aux accomodements réciproques? „Cahiers du CEDIE working papers” 2011, no. 3.

Dąbrowski Ł.D.: Moc dowodowa zagranicznych dokumentów urzędowych. Wybrane zagadnienia procesowe. „Problemy Współczesnego Prawa Międzynarodowego, Europejskiego i Porównawczego" 2016, vol. 14.

Deif F.: Divorced from Justice: Women's Unequal Access to Divorce in Egypt. „Human Rights Watch” 2004, vol. 16, no. 8.

Enright M.: The Beginning of the Sharpness: Loyalty, Citizenship and Muslim Divorce Practice. „International Journal of Law in Context” 2013, vol. 9, no. 3.

Ereciński T., Ciszewski J., Weitz K.: Kodeks postępowania cywilnego. Komentarz. Warszawa 2009.

Fiorini A.: The Codification of Private International Law: The Belgian Experience. „International Comparative Law Quarterly” 2005, vol. 54. 
Fournier P.: Please divorce me! Subversive agency, resistance and gendered religious scripts. In: Muslim Family Law in Western Courts. Ed. E. Giunchi. Abingdon 2014.

Fournier P.: The reception of Muslim family laws in western liberal states. „Women Living Under Muslim Law Dossier” 2005, vol. 27.

Frańczuk M.: Finanse w matżeństwie muzutmańskim i po jego ustaniu. Porównanie z regulacjami prawa polskiego. „Zeszyty Naukowe Uniwersytetu Ekonomicznego w Krakowie” 2013, nr 901.

Fredriksen K.J.: The recognition of transnational Muslim marriages and divorces by Norwegian courts and other competent authorities: dynamics between legislation and legal practice. In: Muslim Family Law in Western Courts. Ed. E. Giunchi. Abingdon 2014.

Gavalda A.: Remarques sur l'arrêt Rivière. „Travaux du Comité français de droit international privé" 1955, vol. 14.

Goldstein G.: The Recognition and Enforcement of Foreign Decisions in Québec. „Yearbook of Private International Law” 2013/2014, vol. 15.

Isailovic I.: La reconnaissance politique en droit transnational: les identités, les marginalisations et le droit international privé. In: Droit international et reconnaissance. Eds. H. Muir Watt, E. Tourme Jou annet. Paris 2015.

Joubert N.: La notion de liens suffisants avec l'ordre juridique (Inslandsbeziehung) en droit international privé. Paris 2007.

Kamarad E.: Kolizyjnoprawne aspekty matżeństw dzieci. „Problemy Prawa Prywatnego Międzynarodowego" 2019, vol. 24.

Kozioł A., w: Prawo prywatne międzynarodowe. Komentarz. Red. M. Pazdan. Warszawa 2018.

Kozioł A., w: „System Prawa Prywatnego”. T. 20C: Prawo prywatne międzynarodowe. Red. M. Pazdan. Warszawa 2015.

Krüger H.: Prawo mał̇̇eńskie i spadkowe $w$ dzisiejszym świecie orientalnym. „Problemy Prawa Prywatnego Międzynarodowego” 2016, T. 19.

Krzysztofek K.: Dopuszczalność stosowania prawa szariatu w zakresie spraw rozwodowych $i$ spadkowych $w$ prawodawstwie Unii Europejskiej. „Studia z Prawa Wyznaniowego" 2016, vol. 19.

Lagarde P.: Public Policy (chapter 11). In: International Encyclopedia of Comparative Law. Vol. 3: Private International Law. Part 1. Ed. K. Lipstein. Tübingen 1986.

Lagarde P.: Recherches sur l'ordre public en droit international privé. Paris 1959.

Lindbekk M.: Inscribing Islamic Shari“a in Egyptian Divorce Law. „Oslo Law Review" 2016, vol. 3, no. 2.

Łączkowska M.: Zasada trwałości małżeństwa $w$ polskim prawie rodzinnym - aspekty materialne i procesowe. „Studia Prawnoustrojowe” 2014, nr 24.

Margoński M.: Skutki w Polsce poświadczenia dziedziczenia dokonanego przez notariusza holenderskiego. Glosa do postanowienia Sadu Okręowego w Kielcach z dnia 5 lutego 2015 r. (II CA 1533/14, II CZ 1784/14). „Nowy Przegląd Notarialny" 2015, nr 3. 
Mączyński M.: Kodyfikacyjne zagadnienia części ogólnej prawa prywatnego międzynarodowego. W: Studia i rozprawy. Księga jubileuszowa dedykowana profesorowi Andrzejowi Całusowi. Red. A. Janik. Warszawa 2009.

Moosa Al.-R., Helly D.: An analysis of British judicial treatment of Islamic divorces 1997-2009. In: Muslim Family Law in Western Courts. Ed. E. Giunchi. Abingdon 2014.

Nader S.D.: Twenty Years After Gutierrez v. Collins: Public Policy And Conflict Of Laws Analysis In Texas Tort Cases. „Baylor Law Review” 2000, vol. 52.

O’Brien J.: Conflict of Laws. $2^{\text {nd }}$ ed. London 1999.

Pazdan M.: Prawo prywatne międzynarodowe. Warszawa 2017.

Pietrzykowski K.: Zawarcie małżeństwa i przestanki jego ważności w prawie międzynarodowym prywatnym. Warszawa 1985.

Pilich M.: Zasada obywatelstwa $w$ prawie prywatnym międzynarodowym. Warszawa 2015.

Pisarek J.: Stosunek władz Bawarii do mniejszości muzutmańskich. „Studia Oecumenica" 2014, nr 14.

Piwko A.M.: Muzutmańskie prawo rodzinne: sposoby rozwiazania matżeństwa $w$ islamie oraz zasady dziedziczenia majatku. „Nurt SVD” 2013, nr 1.

Piwko A.M.: Rozwód w islamie. „Nurt SVD” 2013 [wyd. specjalne].

Podkowik J.: Prawo rzeczowe, spadkowe i rodzinne $w$ orzecznictwie Trybunatu Konstytucyjnego. „Kwartalnik Prawa Prywatnego” 2017, z. 4.

Przybyłowski K.: Prawo prywatne międzynarodowe. Część ogólna. Lwów 1935.

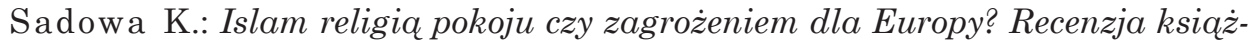
ki Marka Orzechowskiego „Mój sqsiad islamista. Kalifat u drzwi Europy”. „Wrocławskie Studia Erazmiańskie” 2015, T. 9.

Sadowa K.: Oddziaływanie szariatu na orzecznictwo europejskie $i$ europejski porzadek prawny na przykładzie Niemiec $i$ Wielkiej Brytanii - zarys problematyki. W: „Acta Erasmiana”. T. 7: Z badań nad prawem i administracja. Red. M. Sadowski. Wrocław 2014.

Sadowski M.: Kontrakt matżeński w prawie islamu. „Studia Prawno-Ekonomiczne" 2017, T. 103.

Sadowski M.: Matżeństwo w prawie islamu. Poznań 2015.

Sadowski M.: Rozwód wedtug procedury „talaq” w prawie islamu. „Radca Prawny - Zeszyty Naukowe” 2017, nr 3.

Salem N.: The Impact of the Convention on the Elimination of All Forms of Discrimination against Women on the Domestic Legislation in Egypt. Leiden-Boston 2018.

Sapota A.: Wybór prawa $w$ międzynarodowym prawie rodzinnym. Warszawa 2016.

Schwab D.: Jak matżeństwo trafiło do sadu. „Kwartalnik Prawa Prywatnego” 2017, z. 2.

Sinay-Cytermann A.: Les tendances actuelles de l'ordre public international. In: Mélanges en l’honneur du Professeur Bernard Audit: Les relations privées internationals. Paris 2014. 
Smyczyński T.: Prawo rodzinne i opiekuńcze. Wyd. 9. Warszawa 2018.

Sośniak M.: Klauzula porzqdku publicznego $w$ prawie międzynarodowym prywatnym. Warszawa 1961.

Sośniak M.: Zasada równorzędności ptci w zakresie zawarcia, unieważnienia $i$ rozwiazania małżeństwa $w$ socjalistycznych systemach prawa międzynarodowego prywatnego ze szczególnym uwzględnieniem prawa polskiego. „Studia Prawnicze" 1978, nr 3.

Sportel I.: Divorce in Transnational Families: Marriage, Migration and Family Law. Palgrave Mcmillian 2016.

Stru miłło T., w: Kodeks postępowania cywilnego. T. 2: Komentarz. Art. 7301217. Red. J. Jankowski. Wyd. 2. Warszawa 2015, kom. do art. 11491.

Symeonides S.: Choice of Law in the American Courts in 2015: Twenty-Ninth Annual Survey. „American Journal of Comparative Law” 2016, vol. 64.

Tomaszewski M.: W sprawie skuteczności w Polsce zagranicznych rozwodów administracyjnych. „Państwo i Prawo” 1979, z. 8-9.

Torbus A., w: Komentarz do kodeksu postępowania cywilnego. T. 4. Red. K. Piasecki, A. Marciniak. Warszawa 2017, art. 1098.

Vrellis S.: Conflit ou coordination de valeurs en droit International privé. „Receuil des Cours” 2007, vol. 328.

Wojewoda M.: Moc dowodowa zagranicznych dokumentów urzędowych. W: „System Prawa Prywatnego". T. 20C: Prawo prywatne międzynarodowe. Red. M. Pazdan. Warszawa 2015.

Zachariasiewicz M.: Klauzula porzqdku publicznego jako instrument ochrony materialnoprawnych interesów i wartości fori. Warszawa 2018.

Zachariasiewicz M., w: Prawo prywatne międzynarodowe. Komentarz. Red. M. Pazdan. Warszawa 2018.

Zekić M.: Status kobiety w islamskiej teorii i praktyce. „Ways to Religion” 2018, T. 2 . 